Article

\title{
Expression and Activity of TRPA1 and TRPV1 in the Intervertebral Disc: Association with Inflammation and Matrix Remodeling
}

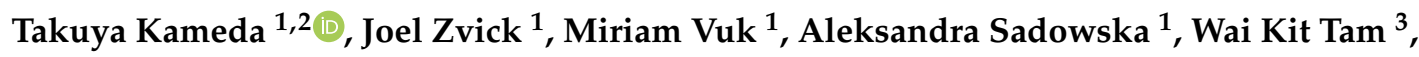 \\ Victor Y. Leung ${ }^{3}$, Kata Bölcskei ${ }^{4,5}$, Zsuzsanna Helyes ${ }^{4,5}$, Lee Ann Applegate ${ }^{6}$, \\ Oliver N. Hausmann ${ }^{7}$, Juergen Klasen ${ }^{8}$, Olga Krupkova ${ }^{1, *,+}$ (D) and Karin Wuertz-Kozak $1,9,10,+(\mathbb{D}$ \\ 1 Institute for Biomechanics, ETH Zurich, Hoenggerbergring 64, 8093 Zurich, Switzerland; \\ sa57384@cd6.so-net.ne.jp (T.K.); joel.zvick@hest.ethz.ch (J.Z.); vukm@student.ethz.ch (M.V.); \\ aleksandra.sadowska@hest.ethz.ch (A.S.); kwuertz@ethz.ch (K.W.-K.) \\ 2 Department of Orthopaedic Surgery, Fukushima Medical University, 1 Hikarigaoka, Fukushima City, \\ Fukushima 960-1295, Japan \\ 3 Department of Orthopaedics and Traumatology, The University of Hong Kong, 21 Sassoon Road, Pokfulam, \\ Hong Kong SAR, China; tamwk1@hku.hk (W.K.T.); vicleung@hku.hk (V.Y.L.) \\ 4 Department of Pharmacology and Pharmacotherapy, University of Pécs, Szigeti út 12., \\ H-7624 Pécs, Hungary; kata.bolcskei@aok.pte.hu (K.B.); zsuzsanna.helyes@aok.pte.hu (Z.H.) \\ 5 János Szentágothai Research Centre, University of Pécs, Ifjúság útja 20., H-7624 Pécs, Hungary \\ 6 Department of Musculoskeletal Medicine, Unit of Regenerative Therapy (UTR), \\ University Hospital Lausanne, EPCR/02 Chemin des Croisettes 22, 1066 Epalinges, Switzerland; \\ Lee.Laurent-Applegate@chuv.ch \\ 7 Neuro- and Spine Center, St. Anna Hospital, Sankt-Anna-Strasse 32, 6006 Luzern, Switzerland; \\ ohausmann@hin.ch \\ 8 Clinic Prodorso, Walchestrasse 15, 8006 Zurich, Switzerland; info@prodorso.ch \\ 9 Schön Clinic Munich Harlaching, Spine Center, Academic Teaching Hospital and Spine Research Institute of \\ the Paracelsus Medical University Salzburg (AU), Harlachinger Str. 51, 81547 Munich, Germany \\ 10 Department of Health Sciences, University of Potsdam, Am Neuen Palais 10, 14469 Potsdam, Germany \\ * Correspondence: okrupkova@ethz.ch; Tel.: +41-44-633-2901 \\ + The authors contributed equally to this work.
}

Received: 7 March 2019; Accepted: 30 March 2019; Published: 10 April 2019

\begin{abstract}
Transient receptor potential (TRP) channels have emerged as potential sensors and transducers of inflammatory pain. The aims of this study were to investigate (1) the expression of TRP channels in intervertebral disc (IVD) cells in normal and inflammatory conditions and (2) the function of Transient receptor potential ankyrin 1 (TRPA1) and Transient receptor potential vanilloid 1 (TRPV1) in IVD inflammation and matrix homeostasis. RT-qPCR was used to analyze human fetal, healthy, and degenerated IVD tissues for the gene expression of TRPA1 and TRPV1. The primary IVD cell cultures were stimulated with either interleukin-1 beta (IL-1 $\beta$ ) or tumor necrosis factor alpha (TNF- $\alpha$ ) alone or in combination with TRPA1/V1 agonist allyl isothiocyanate (AITC, 3 and $10 \mu \mathrm{M}$ ), followed by analysis of calcium flux and the expression of inflammation mediators (RT-qPCR/ELISA) and matrix constituents (RT-qPCR). The matrix structure and composition in caudal motion segments from TRPA1 and TRPV1 wild-type (WT) and knock-out (KO) mice was visualized by FAST staining. Gene expression of other TRP channels (A1, C1, C3, C6, V1, V2, V4, V6, M2, M7, M8) was also tested in cytokine-treated cells. TRPA1 was expressed in fetal IVD cells, $20 \%$ of degenerated IVDs, but not in healthy mature IVDs. TRPA1 expression was not detectable in untreated cells and it increased upon cytokine treatment, while TRPV1 was expressed and concomitantly reduced. In inflamed IVD cells, $10 \mu \mathrm{M}$ AITC activated calcium flux, induced gene expression of IL-8, and reduced disintegrin and metalloproteinase with thrombospondin motifs 5 (ADAMTS5) and collagen 1A1, possibly via upregulated TRPA1. TRPA1 KO in mice was associated with signs of
\end{abstract}


degeneration in the nucleus pulposus and the vertebral growth plate, whereas TRPV1 KO did not show profound changes. Cytokine treatment also affected the gene expression of TRPV2 (increase), TRPV4 (increase), and TRPC6 (decrease). TRPA1 might be expressed in developing IVD, downregulated during its maturation, and upregulated again in degenerative disc disease, participating in matrix homeostasis. However, follow-up studies with larger sample sizes are needed to fully elucidate the role of TRPA1 and other TRP channels in degenerative disc disease.

Keywords: low back pain; TRP channels; pro-inflammatory cytokines; aggrecanases; collagen; TRPA1; TRPV1; TRPV2; TRPV4; TRPC6

\section{Introduction}

Low back pain (LBP) is the leading cause of disability, activity limitation and lost productivity throughout the world today, with approximately $80 \%$ of all people suffering from back pain at least once in their life [1]. Degenerative disc disease (DDD), which is a progressive multifactorial disorder of the intervertebral disc (IVD), is an important factor that is involved in the development of LBP [1]. DDD is characterized by the release of inflammatory and catabolic mediators, including interleukin-1 beta (IL-1 $\beta)$, tumor necrosis factor alpha (TNF- $\alpha$ ), prostaglandins, and proteases, which further promote the degradation of extracellular matrix (ECM) [2,3]. Pro-inflammatory cytokines IL-1 $\beta$ and TNF- $\alpha$ directly act as nociceptive triggers, but also activate the expression of other potentially nociceptive molecules including neuropeptides, interleukin-6 (IL-6), and interleukin-8 (IL-8) [4,5]. Molecular mechanisms involved in transduction and modulation of IL- $1 \beta$ and TNF- $\alpha$ signaling in DDD are not yet well-understood [6-8].

Signals that are provided by pro-inflammatory cytokines can be mediated via membrane channels $[9,10]$. Recently, transient receptor potential (TRP) channels have emerged as putative receptors for inflammation-associated molecules, positive/negative regulators of inflammation, and transducers of inflammatory pain [11-13]. TRP channels are cation selective transmembrane receptors with diverse physiological functions. Six families of mammalian TRP channels have been identified, classifying TRP channels according to their sequence homology and topological differences: TRPA (ankyrin), TRPC (canonical), TRPM (melastatin), TRPV (vanillin), TRPP (polycystin), and TRPML (mucolipin). Apart from TRPA, every subfamily has several members [14,15]. The dysregulation of TRP channels is implicated in many pathologies, including cardiovascular diseases, muscular dystrophies, and hyperalgesia [14,16]. Interestingly, the expression and activity of certain TRP channels is altered in painful joints and IVDs [11,12]. For example, the expression of TRPV4 in human IVDs was found to be elevated in regions of aggrecan depletion [17], while the gene expression of TRPC6 was associated with the severity of disc degeneration, increased expression of IL-6, and cell senescence $[18,19]$. TRPA1 and TRPV1 are involved in inflammation/nociception in sensory neurons and non-neuronal tissues [20-22]. TRPV1 is a non-selective calcium channel, the expression and activity of which increases after inflammatory stimulation in dorsal root ganglions (DRGs), possibly causing chronic hyperalgesia. TRPV1 also expressed in chondrocytes [23]. TRPA1 is a calcium permeable non-selective cation channel that is also widely expressed in sensory neurons and in non-neuronal cells, including chondrocytes [11]. TRPA1 is involved in various sensory and homeostatic functions, depending on the cell type [12,24]. TRPA1 and TRPV1 were shown to complement each other's activities [21,25]. As numerous publications have linked TRPA1 and TRPV1 with inflammatory pain [21], therapeutic inhibition or the activation of TRPA1 and/or TRPV1 channels may be beneficial in the treatment of DDD. Therefore, the aims of this study were to investigate the (1) expression of TRP channels in IVD cells in normal and inflammatory conditions and (2) the function of TRPA1 and TRPV1 in disc inflammation and matrix homeostasis. 


\section{Results}

\subsection{Gene Expression of TRPA1 in Human IVD Tissue}

Gene expression of TRPA1 was tested in human non-degenerated $(n=4)$ and degenerated $(n=20)$ IVD tissue in relation to disc region, disease type, pain score (for degenerated discs only), grade, and age. In the degenerated tissue, TRPA1 was found expressed in $20 \%$ of tested donors (four out of 20). Although only expressed in a subset of degenerated donors, TRPA1 was found in both annulus fibrosus (AF) and nucleus pulposus (NP), in an age range of 39-76 years, at pain scores 2 (= intense) and 3 (= disabling) and at Pfirrmann grades 2 and 3 (Table 1). TRPA1 was only expressed in one non-degenerated NP sample (in one out of four donors: male, 17 years old, grade 1, $\left.2^{-\mathrm{dCt}}=4.57 \times 10^{-5}\right)$. Interestingly, TRPA1 was found expressed in cells isolated from human fetal IVD tissue $\left(n=4 ; 2^{-\mathrm{dCt}}=0.0463 \pm 0.04742\right)$. It is known that TRPA1 can associate with TRPV1, thereby regulating its intrinsic properties independently of intracellular calcium. Table 1 summarizes the expression of TRPV1. A manuscript that provides details on the expression of TRPV1 in IVD tissue is currently in revision [26].

Table 1. Gene expression of TRPA1 and TRPV1 in human intervertebral disc (IVD) tissue. Some donor tissues were divided into nucleus pulposus (NP) and annulus fibrosus (AF), resulting in more AF and NP samples ( $n=21$ in region, pain score, grade) than a total number of donors $(n=20)$.

\begin{tabular}{|c|c|c|c|c|c|c|}
\hline $\begin{array}{l}\text { Degenerated } \\
\text { Lumbar IVDs }\end{array}$ & $n$ & $2^{-\mathrm{d} C \mathrm{t}}($ Mean $\pm \mathrm{SD})$ & Region & Pain score & Grade & Age (Mean \pm SD) \\
\hline TRPA1 & in 4 out of 20 & $0.0006 \pm 0.001$ & $\begin{array}{l}2 \text { in } \mathrm{AF} \\
2 \text { in } \mathrm{NP}\end{array}$ & $\begin{array}{l}2 \text { pain score } 2 ; \\
2 \text { pain score } 3\end{array}$ & $\begin{array}{l}2 \text { grade } 2 ; \\
2 \text { grade } 3\end{array}$ & $\begin{array}{l}60 \pm 15.6 \\
\max : 76 \\
\min : 39\end{array}$ \\
\hline TRPV1 [26] & 19 out of 20 & $0.0047 \pm 0.0024$ & $\begin{array}{l}10 \text { in NP } \\
9 \text { in } \mathrm{AF} \\
2 \text { in mix }\end{array}$ & $\begin{array}{c}6 \text { in pain score } 1 ; \\
11 \text { in pain score } 2 ; \\
4 \text { in pain score } 3\end{array}$ & $\begin{array}{l}4 \text { grade } 2 ; \\
8 \text { grade } 3 ; \\
6 \text { grade } 4 ; \\
3 \text { grade } 5\end{array}$ & $\begin{array}{l}54 \pm 15 \\
\max : 80 \\
\min : 31\end{array}$ \\
\hline
\end{tabular}

\subsection{Gene Expression of TRPA1 and TRPV1 in Human IVD Cells Treated with Pro-Inflammatory Cytokines}

TRPA1 and TRPV1 can be involved in modulating inflammation in both neuronal and non-neuronal cells [25]. Therefore, changes in the gene expression of TRPA1 and TRPV1 were tested in IVD cells stimulated with pro-inflammatory cytokines IL- $1 \beta$ and TNF- $\alpha$ (both 5 and $10 \mathrm{ng} / \mathrm{mL})(n=5$ ) (Table 2). TRPA1 was under the detection limit in most untreated IVD cells, while its gene expression tended to increase with IL-1 $\beta$ treatment ( $p=0.07$ for IL-1 $5 \mathrm{ng} / \mathrm{mL}$ ) and it significantly increased with TNF- $\alpha$ (Figure 1A). TNF- $\alpha$, but not IL-1 $\beta$, significantly reduced gene expression of TRPV1 (Figure 1B). The induction of an inflammatory-catabolic shift upon cytokine treatment was demonstrated by an increase of IL-6, IL-8, cyclooxygenase-2 (COX-2), nerve growth factor (NGF), matrix metalloproteinase 1 (MMP1), matrix metalloproteinase 3 (MMP3), a disintegrin and metalloproteinase with thrombospondin motifs 4 (ADAMTS4), a disintegrin and metalloproteinase with thrombospondin motifs 5 (ADAMTS5), and a reduction in COL2A1. Tissue inhibitor of matrix metalloproteinase 1 (TIMP1), tissue inhibitor of matrix metalloproteinase 2 (TIMP2), Aggrecan and COL1A1 were unchanged (Supplementary Figure S1). In IVD cells seeded in three-dimensional (3D) alginate beads and treated with IL-1 $\beta$ (5 ng/mL, 15 days, $n=4-10$ ), gene expression of TRPA1 significantly increased on day 1,8 , and 15 (Figure 1C), while the gene expression of TRPV1 remained unchanged (Figure 1D). Immunostaining confirmed TRPA1 protein induction upon IL-1 $\beta$ treatment $(5 \mathrm{ng} / \mathrm{mL})(n=3)($ Figure $1 \mathrm{E})$. Cell viability in alginate beads was monitored by Calcein/Ethidium homodimer staining and an average of $87 \%$ of living cells per treatment and time point was found (Supplementary Figure S2). 

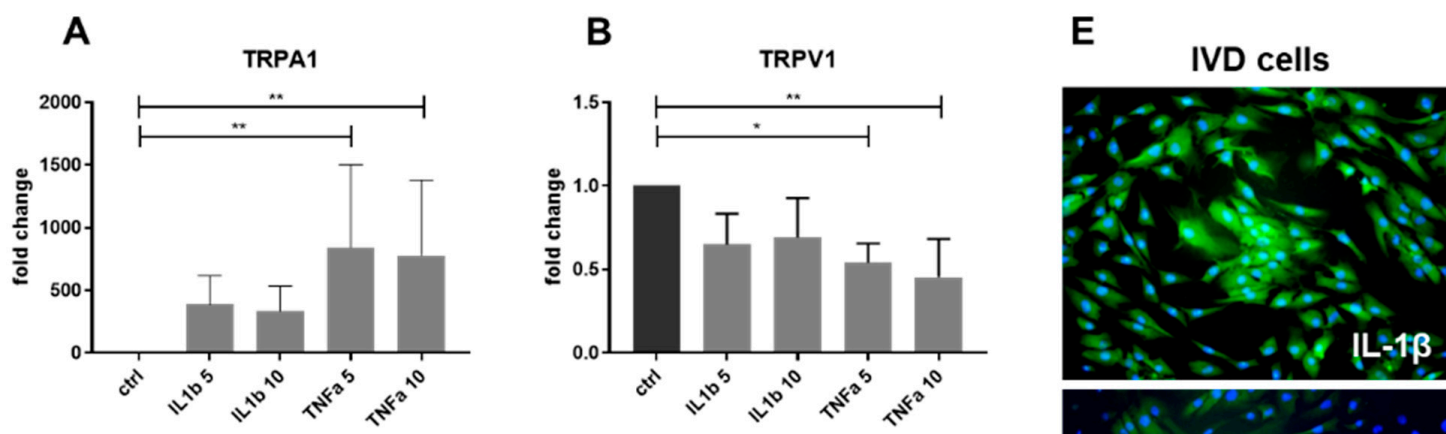

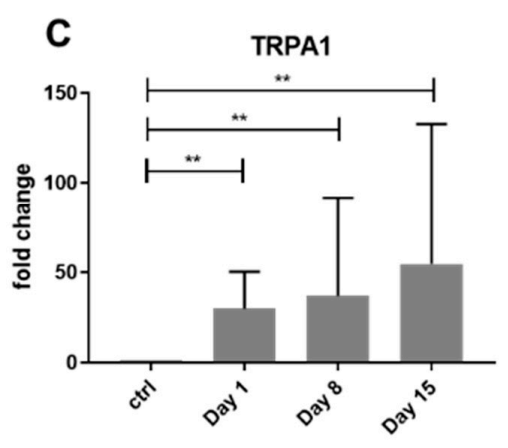

IL-1b $(5 \mathrm{ng} / \mathrm{mL})$

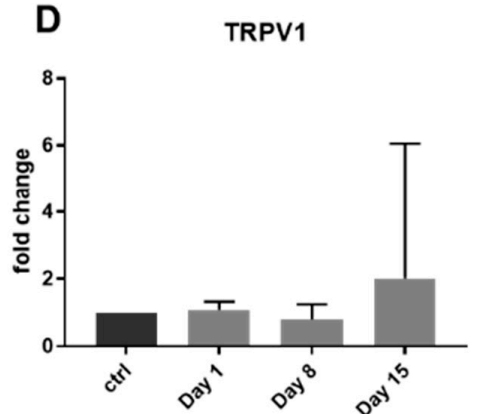

IL-1b $(5 \mathrm{ng} / \mathrm{mL})$

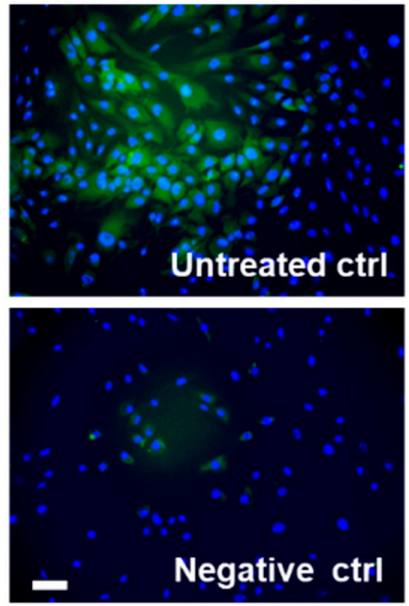

Figure 1. Gene expression of TRPA1 and TRPV1 in IVD cells treated with 5 and $10 \mathrm{ng} / \mathrm{mL}$ interleukin-1 beta (IL-1 $\beta$ ) or tumor necrosis factor alpha (TNF- $\alpha$ ). Gene expression of (A) TRPA1 and (B) TRPV1 in two-dimensional (2D) culture (Graph shows $2^{-\mathrm{ddCt}}$ (mean $\pm \mathrm{SD}, n=5$ ). Gene expression of $(\mathrm{C})$ TRPA1 and (D) TRPV1 in IVD cells cultured in three-dimensional (3D) alginate beads and treated with IL-1 $\beta$ for 15 days. Graph shows $2^{-\mathrm{ddCt}}$ (mean $\pm \mathrm{SD}, n=4-10$ ). Asterisks indicate statistical significance $\left({ }^{*} p<0.05,{ }^{* *} p<0.01\right.$, Kruskal-Wallis test and Dunn's multiple comparison test). (E) Protein expression of TRPA1 in IVD cells treated with IL-1 $\beta$ and untreated (DAPI = blue, TRPA1 = green). Negative control images show cells without secondary antibody. Scale bar is $50 \mu \mathrm{m}$.

Table 2. Gene expression of TRPA1 and TRPV1 in untreated and treated human IVD cells (2D). $n=5$ donors. Values show fold change relative to the untreated cells. In case of expression under the detection limit, $\mathrm{dC}_{\mathrm{t}}$ was set at 40 cycles.

\begin{tabular}{cccccc}
\hline Treatment & Untreated & IL-1 $\beta \mathbf{5} \mathbf{~ n g} / \mathbf{m L}$ & IL-1 $\beta \mathbf{~ 1 0 ~} \mathbf{~ g} / \mathbf{m L}$ & TNF- $\alpha \mathbf{5} \mathbf{n g} / \mathbf{m L}$ & TNF- $\alpha \mathbf{1 0} \mathbf{~ n g} / \mathbf{m L}$ \\
\hline \multirow{2}{*}{ TRPA1 } & $\begin{array}{c}\text { No } \\
\text { expression }\end{array}$ & $385.18 \pm 233.06$ & $333.42 \pm 199.80$ & $842.06 \pm 659.98$ & $780.23 \pm 600.17$ \\
\hline TRPV1 & Expression & $0.64 \pm 0.18$ & $0.69 \pm 0.23$ & $0.53 \pm 0.11$ & $0.45 \pm 0.22$ \\
\hline
\end{tabular}

\subsection{Gene Expression of Other TRP Channels in Human IVD Cells Treated with Pro-Inflammatory Cytokines}

Changes in the gene expression of other TRP channels, namely TRPC1, TRPC3, TRPC6, TRPV2, TRPV4, TRPV6, TRPM2, TRPM7, and TRPM8, were also tested in IVD cells upon cytokine stimulation (IL-1 $\beta$ and TNF- $\alpha$, both 5 and $10 \mathrm{ng} / \mathrm{mL})(n=5)$. IL- $1 \beta$ significantly induced gene expression of TRPV4 and reduced TRPC6. TNF- $\alpha$ significantly activated the gene expression of TRPV2. The expression of other TRP channels showed no clear association with a pro-inflammatory treatment in the tested experimental settings (Figure 2A-G). Gene expression of TRPM2 and TRPM8 was under the detection limit in all of the treatment groups. 

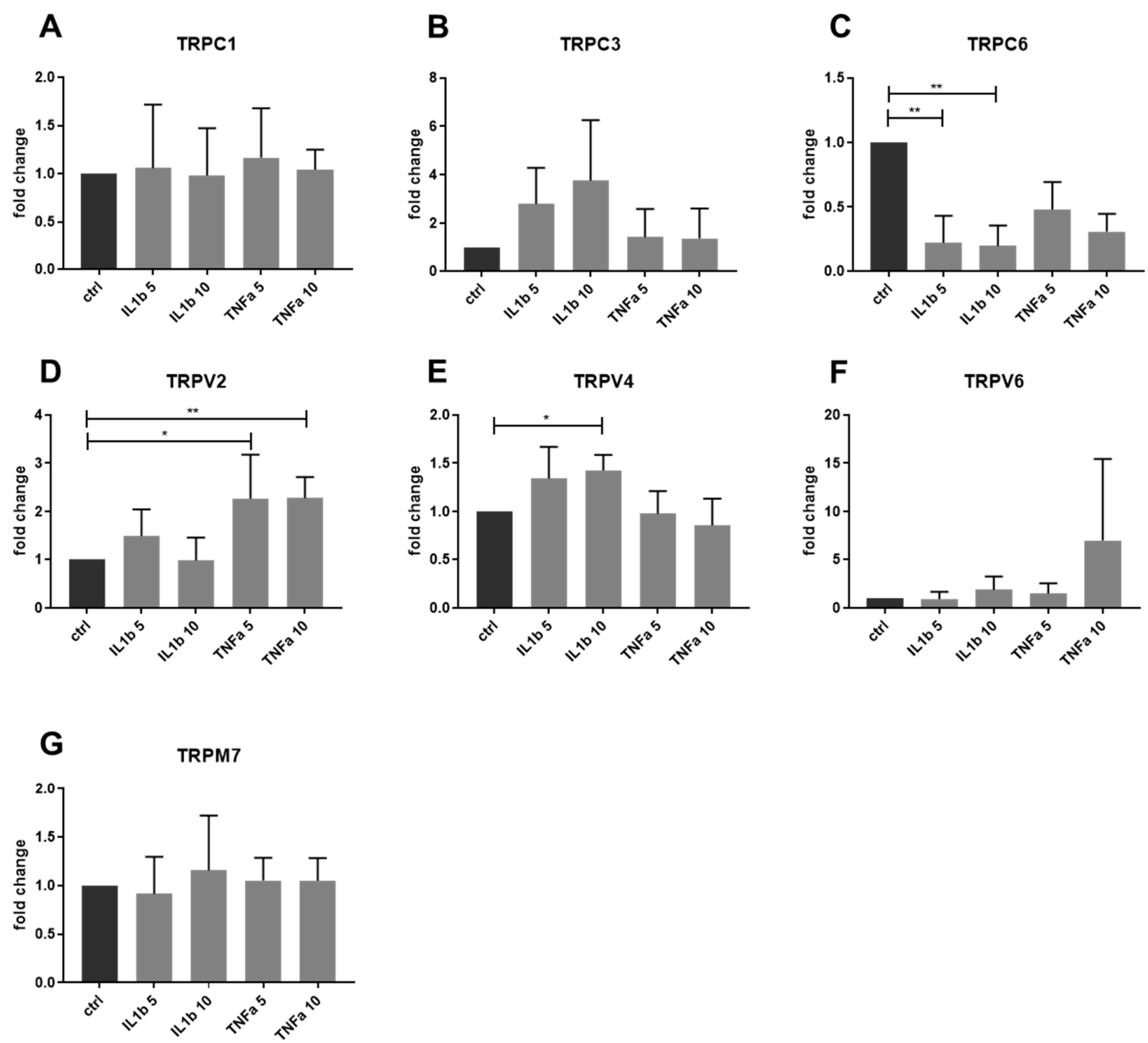

Figure 2. Gene expression of TRP channels in IVD cells treated with 5 and $10 \mathrm{ng} / \mathrm{mL}$ IL-1 $\beta$ or TNF- $\alpha$. Gene expression of (A) TRPC1, (B) TRPC3, (C) TRPC6, (D) TRPV2, (E) TRPV4, (F) TRPV6, and (G) TRPM7. Graphs show $2^{-\mathrm{ddCt}}$ (mean $\pm \mathrm{SD}, n=5$ ). Asterisks indicate statistical significance ${ }^{*} p<0.05$, ** $p<0.01$, Kruskal-Wallis test and Dunn's multiple comparison test).

\subsection{Functional Analysis of TRPA1 and TRPV1 in IVD Cells}

Allyl isothiocyanate (AITC, 3 and $10 \mu \mathrm{M}$ ), which is an agonist for TRPA1 and TRPV1, was used to test the involvement of these channels in (1) inflammation responses and (2) matrix homeostasis within the IVD compartment. The activity of AITC was tested by Calcium flux assay $(n=3)$. AITC was applied in untreated IVD cells (expressing TRPV1) as well as in cells that were treated with pro-inflammatory cytokines (expressing TRPA1 and TRPV1). AITC did not induce calcium flux in the untreated IVD cells. AITC significantly induced calcium flux in both IL-1 $\beta$ and TNF- $\alpha$-treated cells, suggesting the involvement of TRPA1 (Figure 3). Calcium flux in the TNF- $\alpha$ treated cells was significantly higher than in IL-1 $\beta$-treated cells, likely due to the overall higher induction of TRPA1 expression by TNF- $\alpha$. Therefore, it is possible that TRPA1 (not TRPV1) can be functionally involved in the calcium-induced responses of inflamed IVD cells. To verify the function of TRPA1/TRPV1, AITC was used to study gene and protein expression of inflammation and catabolic mediators in untreated as well as cytokine-treated IVD cells. 


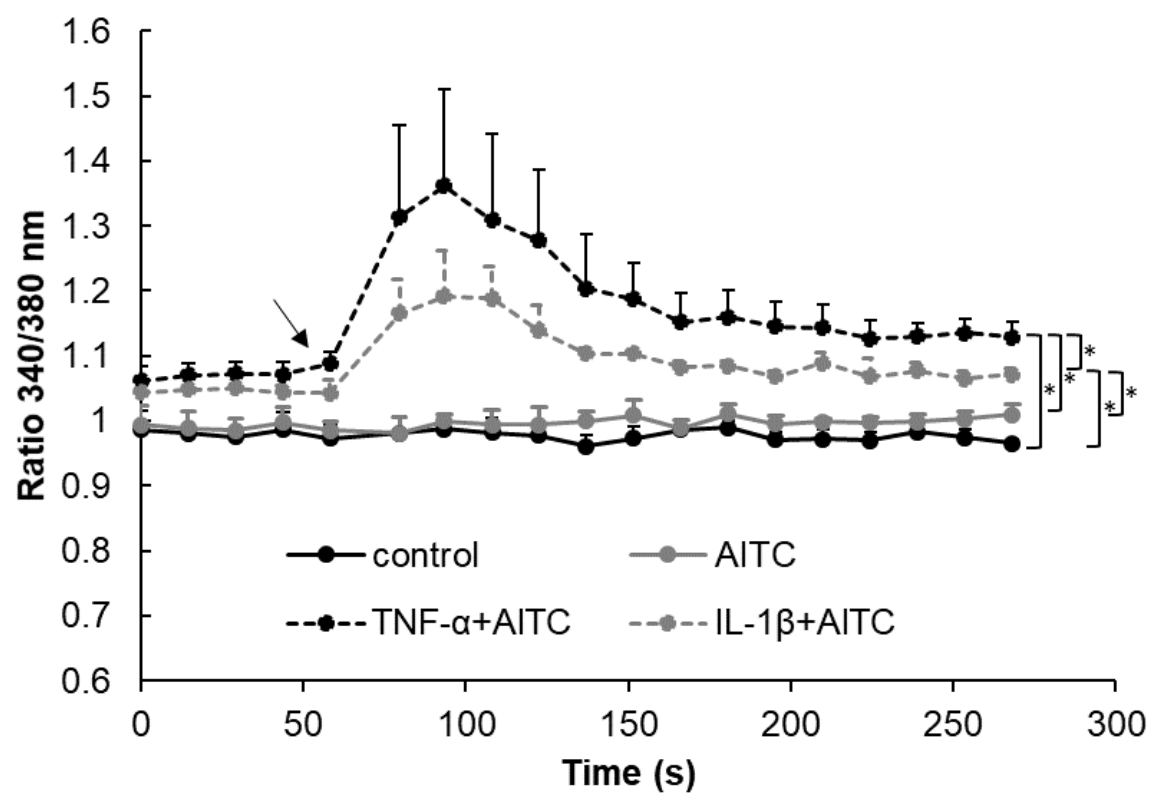

Figure 3. Calcium flux in IVD cells untreated (control) and treated with $100 \mu \mathrm{M}$ Allyl isothiocyanate (AITC) with and without $10 \mathrm{ng} / \mathrm{mL}$ IL-1 $\beta$ or $10 \mathrm{ng} / \mathrm{mL}$ TNF- $\alpha$. Graph shows calcium flux as 340/380 signal ratio (mean $\pm \mathrm{SD}, n=3$ ). Asterisks indicate statistical significance $\left({ }^{*} p<0.05\right.$, Kruskal-Wallis test and Dunn's multiple comparison test). The arrow indicates AITC application.

Cytokine untreated IVD cells (expressing TRPV1) were used to test the downstream effects of TRPV1 activation $(n=3-4)$. In unstimulated IVD cells, the gene expression of inflammation/pain mediators (IL-6, IL-8, NGF, COX-2) (Figure 4A-D) and most of the ECM remodeling enzymes (ADAMTS4, ADAMTS5, MMP3, TIMP1, TIMP2) was unchanged by AITC (Figure 4E-J). IL-6 and IL-8 concentration in culture media was close to the lower detection limit ( zero) (not shown). MMP1 was significantly induced by $10 \mu \mathrm{M}$ AITC (Figure $4 \mathrm{H}$ ). The gene expression of COL1A1, COL2A1, and aggrecan in AITC-treated cells was not significantly different from the control (Figure 4K-M). Due to the fact that cytokine-untreated cells did not express TRPA1, the observed changes in MMP1 expression were not TRPA1-dependent. MMP1 upregulation by AITC may be an unrelated non-specific effect (as AITC did not induce calcium flux in untreated IVD cells).

IVD cells treated with pro-inflammatory cytokines (expressing TRPA1 and TRPV1) were used to test the downstream effects of TRPA1 activation $(n=3-4)$. In IL-1 $\beta$-treated cells, AITC did not influence gene expression of inflammation mediators IL-6 and IL-8 (Figure 5A,D) and pain mediators NGF and COX-2 (Figure 5C,F). Interestingly, the protein release of IL-8 was significantly reduced by $3 \mu \mathrm{M}$ AITC (Figure 5E). $10 \mu \mathrm{M}$ AITC significantly reduced the gene expression of ADAMTS5 (Figure 5H), while MMP1 was induced (Figure 5J). Gene expression of other ECM remodeling enzymes (ADAMTS4, MMP3, TIMP1, TIMP2) and ECM genes (Figure 5M-O) in AITC + IL-1 $\beta$-treated cells was not different from the IL-1 $\beta$-only controls.

$10 \mu \mathrm{M}$ AITC significantly induced the gene and protein expression of IL-8 (Figure 6D,E) in TNF- $\alpha$-treated cells (expressing TRPA1, reduced TRPV1). AITC did not influence the expression of IL-6 (Figure 6A,B), NGF, and COX-2 (Figure 6C,F). The gene expression of ADAMTS5 was significantly reduced (Figure $6 \mathrm{H}$ ), while MMP1 was induced by $10 \mu \mathrm{M}$ AITC in TNF- $\alpha$-treated cells (Figure 6J). Gene expression of other ECM remodeling enzymes (MMP3, ADAMTS4, TIMP1, and TIMP2) was not different from TNF- $\alpha$-treated control. Gene expression of COL1A1 was significantly reduced (Figure $6 \mathrm{M}$ ), while the other tested ECM proteins (COL2A1 and aggrecan) were not influenced by AITC in TNF- $\alpha$-treated cells. AITC did not affect the gene expression of TRPA1 itself (Supplementary Figure S3). 
A

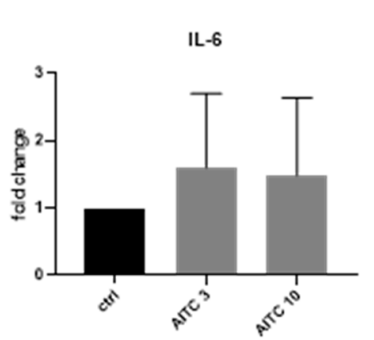

C

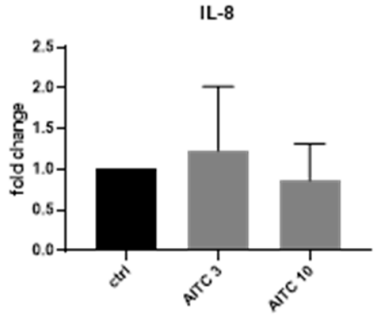

E

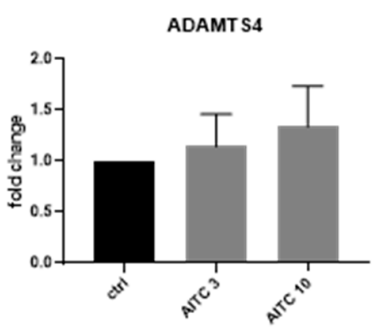

H

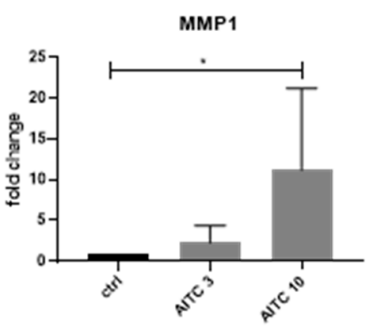

K

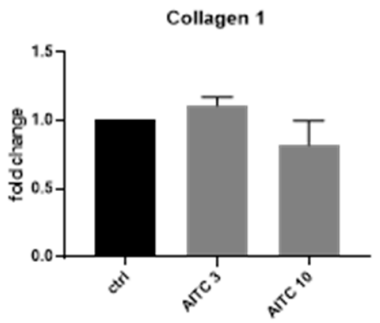

B

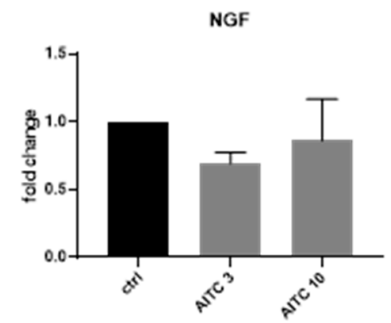

D

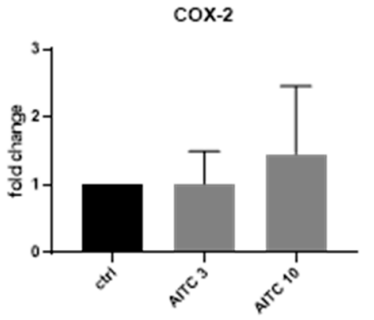

F

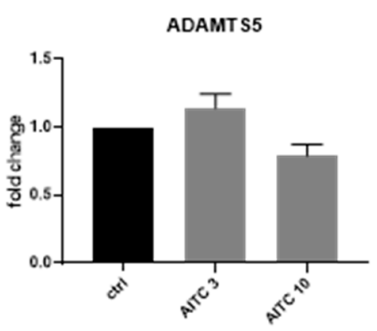

G

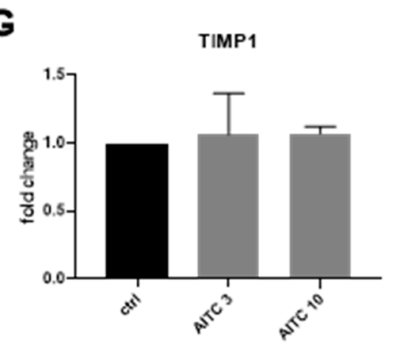

I

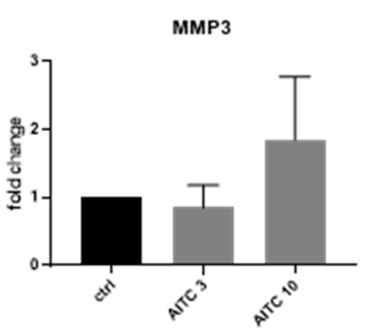

J

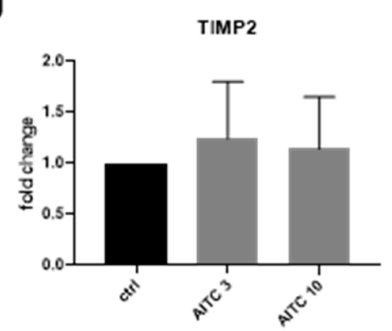

L

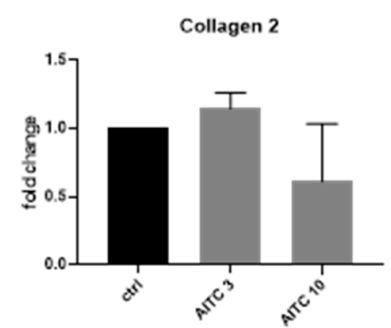

M

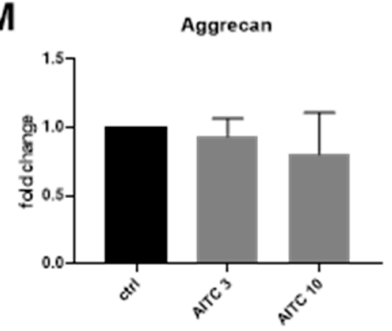

Figure 4. The effects of TRPA1 agonist allyl isothiocyanate (AITC) on the gene expression of inflammation markers and extracellular matrix (ECM) molecules in IVD cells without cytokine pre-treatment. Gene expression of (A) interleukin-6 (IL-6), (B) nerve growth factor (NGF), (C) interleukin 8 (IL-8), (D) cyclooxygenase-2 (COX-2), (E) ADAMTS4, (F) ADAMTS5, (G) tissue inhibitor of matrix metalloproteinase 1 (TIMP1), (H) matrix metalloproteinase 1 (MMP1), (I) matrix metalloproteinase 3 (MMP3), (J) tissue inhibitor of matrix metalloproteinase 2 (TIMP2), (K) COL1A1, (L) COL2A1, and (M) Aggrecan in IVD cells treated with 3 and $10 \mu \mathrm{M}$ AITC. Graphs show gene expression and protein release calculated relative control ( $2^{-\mathrm{ddCt}}$, mean $\left.\pm \mathrm{SD}, n=3\right)$. Asterisks indicate statistical significance ${ }^{*} p<0.05$, Kruskal-Wallis test and Dunn's multiple comparison test). 
A

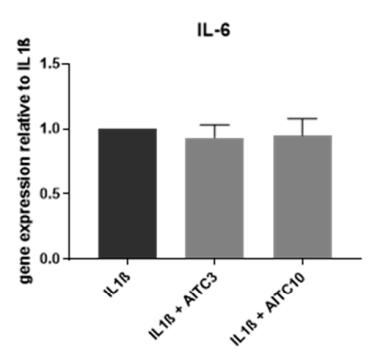

D

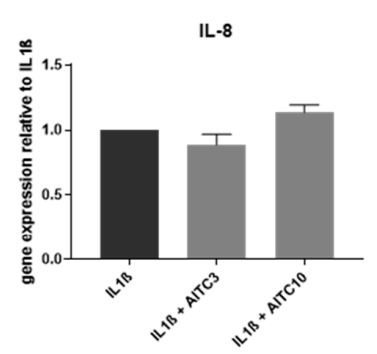

G

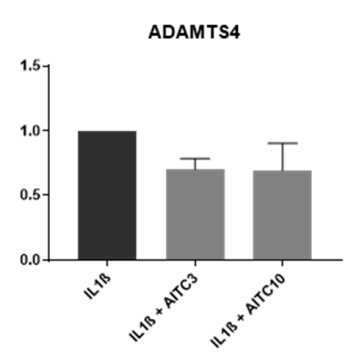

J

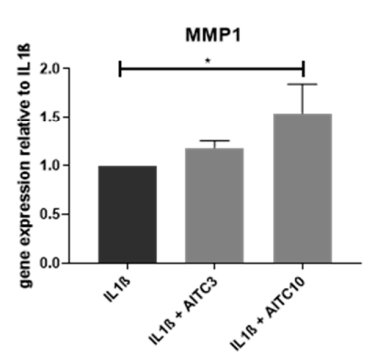

M

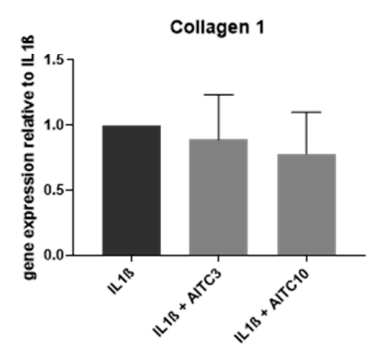

B

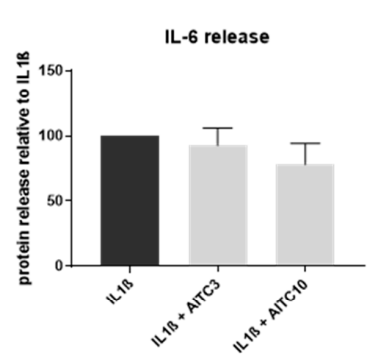

E

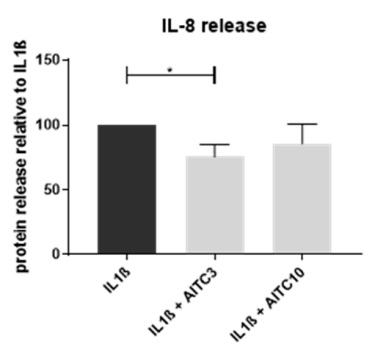

H

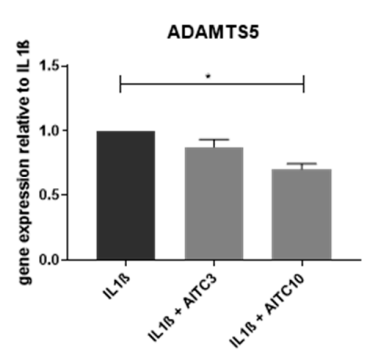

K

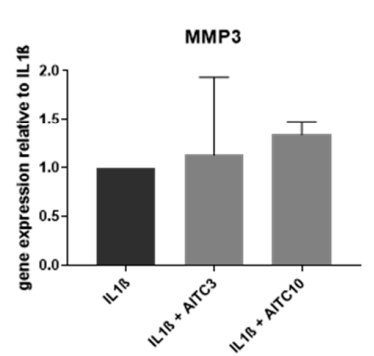

N

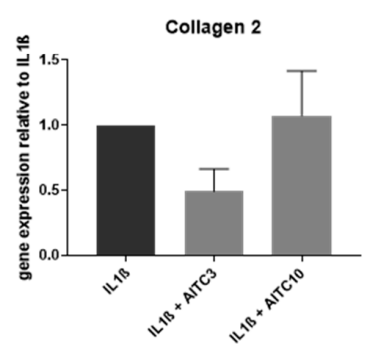

C

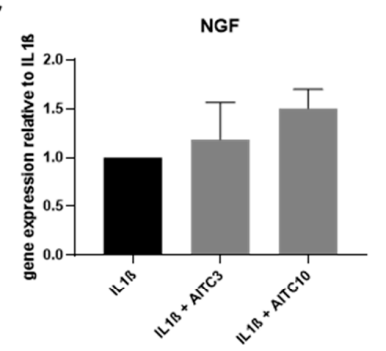

F

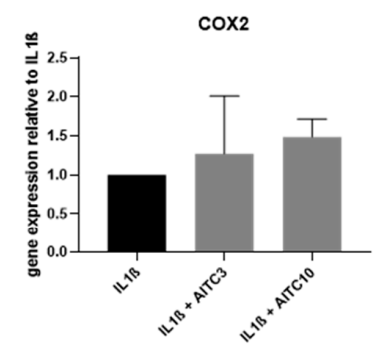

I

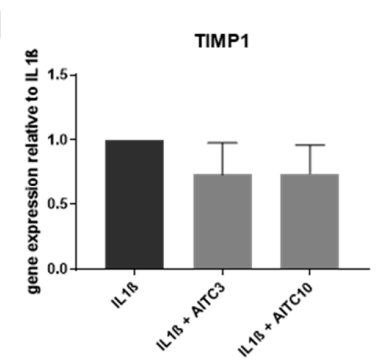

L
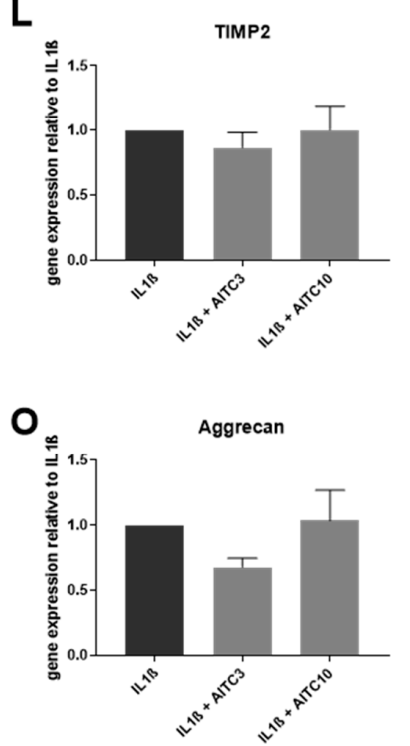

Figure 5. The effects of TRPA1 agonist allyl isothiocyanate (AITC) on the expression of inflammation markers and ECM molecules in IL-1 $\beta$-treated cells. Gene expression of (A) IL-6 and (D) IL-8 in IVD cells treated with $10 \mathrm{ng} / \mathrm{mL}$ IL- $1 \beta \pm 3$ and $10 \mu$ M AITC. Protein release of (B) IL-6 and (E) IL-8 in IVD cells that were treated with $10 \mathrm{ng} / \mathrm{mL}$ IL- $1 \beta \pm 3$ and $10 \mu \mathrm{M}$ AITC. Gene expression of (C) NGF, (F) COX-2, (G) ADAMTS4, (H) ADAMTS5, (J) MMP1, (K) MMP3, (I) TIMP1 and (L) TIMP2, (M) COL1A1, (N) COL2A1, and (O) Aggrecan in IVD cells that were treated with $10 \mathrm{ng} / \mathrm{mL}$ IL-1 $\beta \pm 3$ or $10 \mu \mathrm{M}$ AITC. Graphs show gene expression and protein release calculated relative to IL-1 $\beta$ treatment (mean \pm SD, $n=3-4)$. Asterisks indicate statistical significance $\left({ }^{*} p<0.05\right.$, Kruskal-Wallis test and Dunn's multiple comparison test). 
A

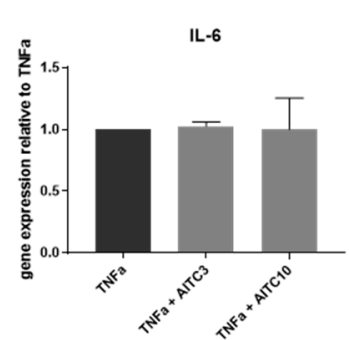

D

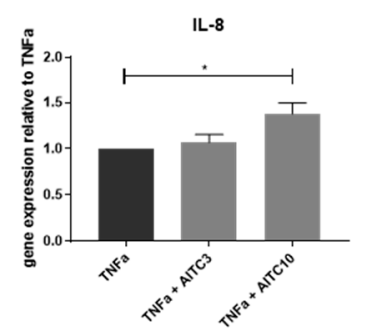

G

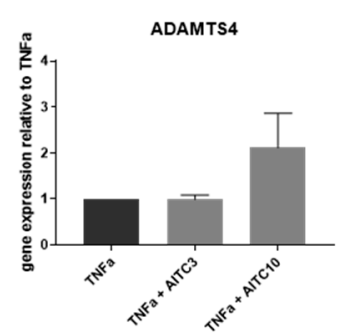

J

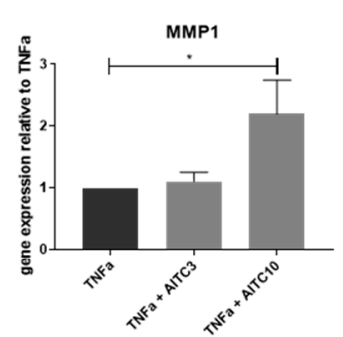

M

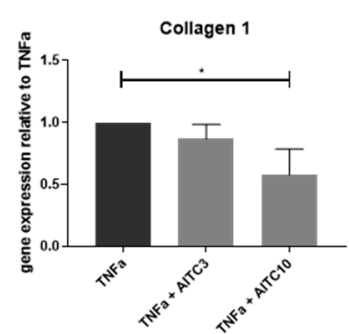

B

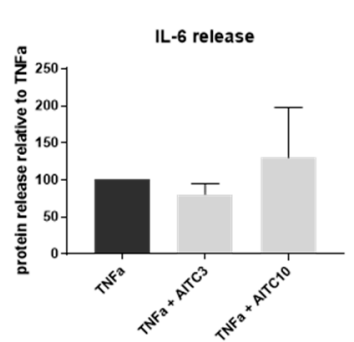

E

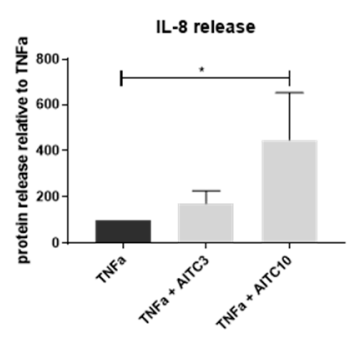

H

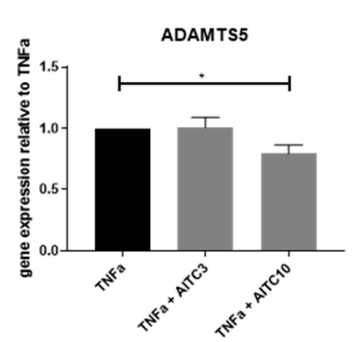

K

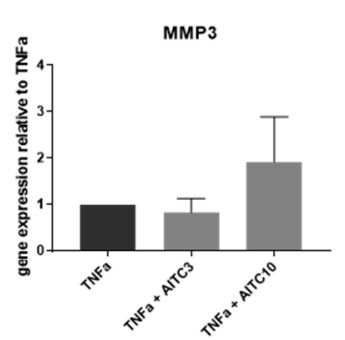

N

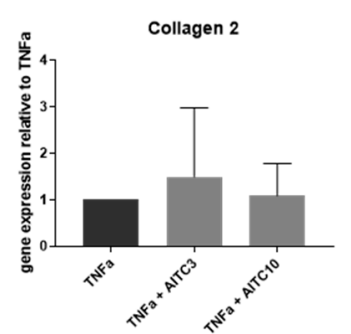

C

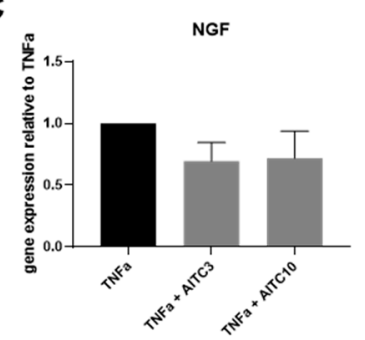

F

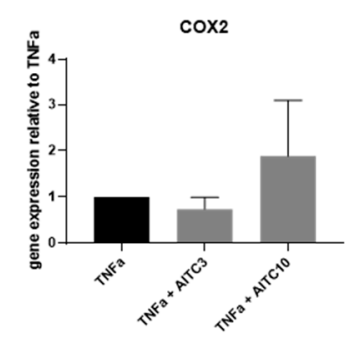

I

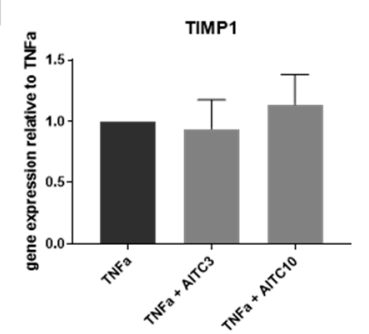

L TIMP2

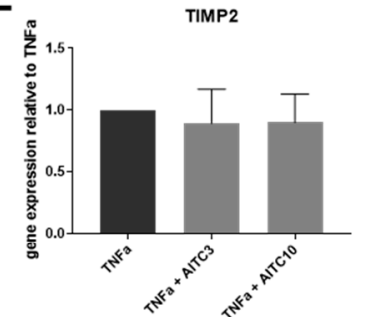

0 Aggrean

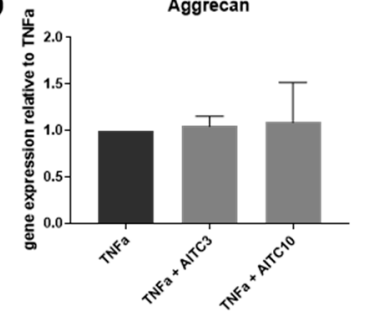

Figure 6. The effects of TRPA1 agonist allyl isothiocyanate (AITC) on gene expression of inflammation markers and ECM molecules in TNF- $\alpha$-treated cells. Gene expression of (A) IL-6 and (D) IL-8 in IVD cells treated with $10 \mathrm{ng} / \mathrm{mL}$ TNF- $\alpha \pm 3$ or $10 \mu \mathrm{M}$ AITC. Protein release of (B) IL-6 and (E) IL-8 in IVD cells treated with $10 \mathrm{ng} / \mathrm{mL}$ TNF- $\alpha \pm 3$ or $10 \mu \mathrm{M}$ AITC. Gene expression of (C) NGF, (F) COX-2, (G) ADAMTS4, (H) ADAMTS5, (I) TIMP1, (J) MMP1, (K) MMP3, and (L) TIMP2, (M) COL1A1, (N) COL2A1, and (O) Aggrecan in IVD cells treated with $10 \mathrm{ng} / \mathrm{mL}$ TNF- $\alpha \pm 3$ and $10 \mu \mathrm{M}$ AITC. Graphs show gene expression and protein release calculated relative to TNF- $\alpha$ treatment (mean \pm SD, $n=3-4)$. Asterisks indicate statistical significance ${ }^{*} p<0.05$, Kruskal-Wallis test and Dunn's multiple comparison test). 


\subsection{Motion Segments of TRPA1 and TRPV1-Deficient Mice}

As our in vitro study showed a possible involvement of TRPA1/TRPV1 in IVD metabolism, we also focused at their effects in vivo. The possible involvement of TRPA1 and TRPV1 in ECM homeostasis was studied by comparing the tail motion segments of young (two months old) and mature (seven months old) TRPA1 wild type (WT) and knock-out (KO) mice ( $n=5$ in each group) as well as young (four months old) and mature (seven months old) TRPV1 KO mice ( $n=5$ in each group). Anatomically, IVD structures from TRPA1 KO and TRPV1 KO mouse were intact with a distinctive central NP tissue, surrounded by lamella fibers of annulus fibrosus (AF) and sandwiched with cartilaginous endplates. However, FAST staining revealed a depletion of sulfated glycoproteins (Alcian blue) in the NP and a reduction of glycosaminoglycan (GAGs) (Safranin O) in the outer AF and vertebral growth plates of matured TRPA1 KO mice, when compared with TRPA1 WT matured controls. No discernible changes of GAG contents were detected in the young TRPA1 KO mouse IVD (Figure 7). On the contrary, no significant changes in the GAG contents were evidenced in the NP and vertebral growth plates of TRPV1 KO mice (Figure 8). The data suggested a functional importance of TRPA1 in GAG production during IVD maturation.
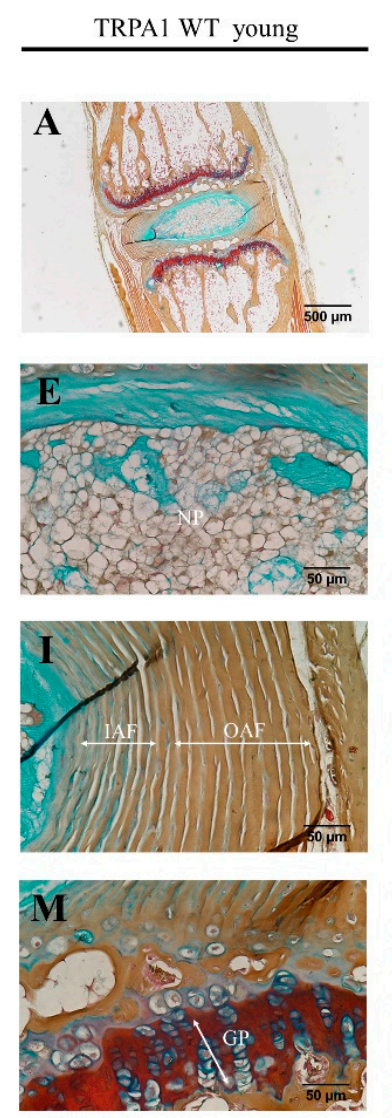
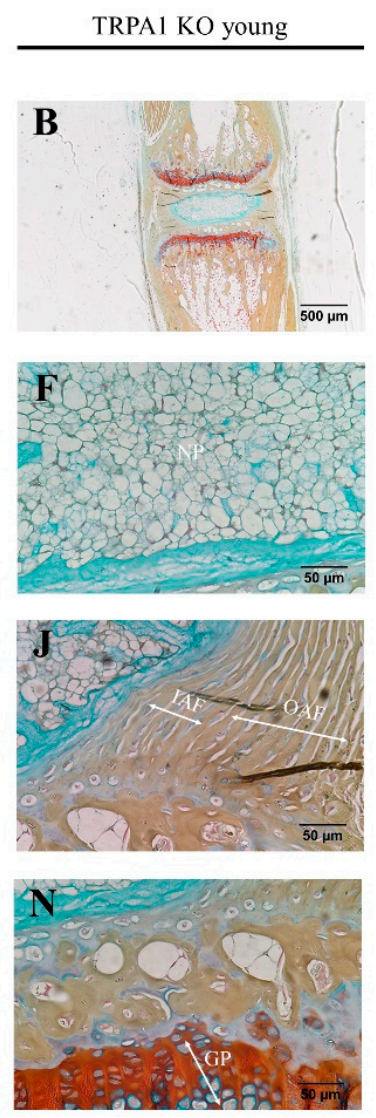

TRPA1 WT old
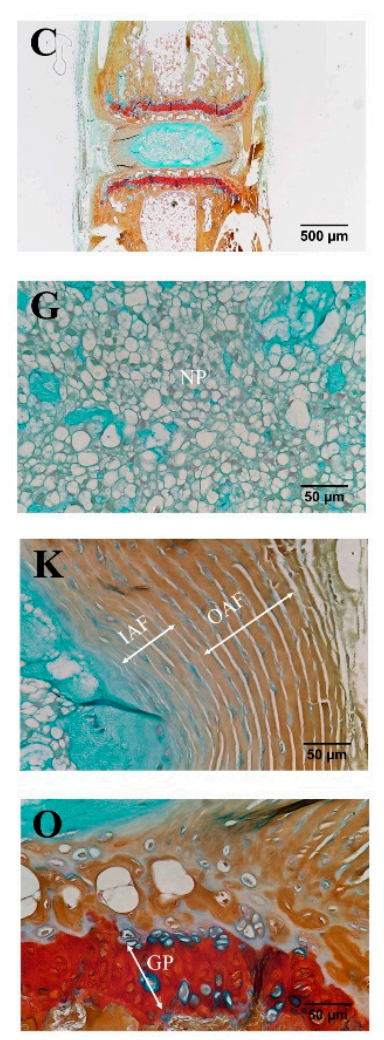

TRPA1 KO old
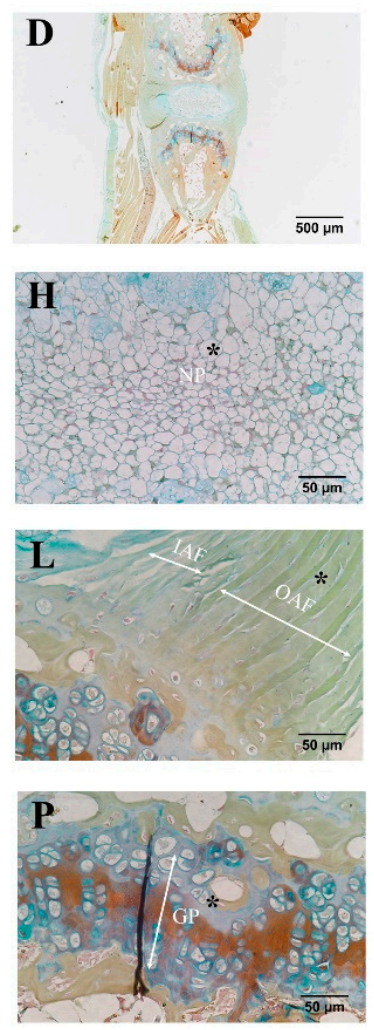

Figure 7. FAST staining of IVDs of TRPA1 wild-type (WT) and knock-out (KO) mice. The tail motion segments of TRPA1 young WT (A,E,I,M), TRPA1 young KO (B,F,J,N), TRPA1 old WT (C,G,K,O), and TRPA1 old $\mathrm{KO}(\mathbf{D}, \mathbf{H}, \mathbf{L}, \mathbf{P})$ mice. The nucleus pulposus: NP (E-H); inner annulus fibrosus: IAF and outer annulus fibrosus: OAF (I-L); vertebral growth plate: GP (M-P) are also shown in higher magnification. Asterisks $\left({ }^{*}\right)$ indicate depletion of glycosaminoglycan deposition in IVD. Scale bars indicate $500 \mu \mathrm{m}$ in upper panel (A-D), but $50 \mu \mathrm{m}$ in lower panels (E-P). 

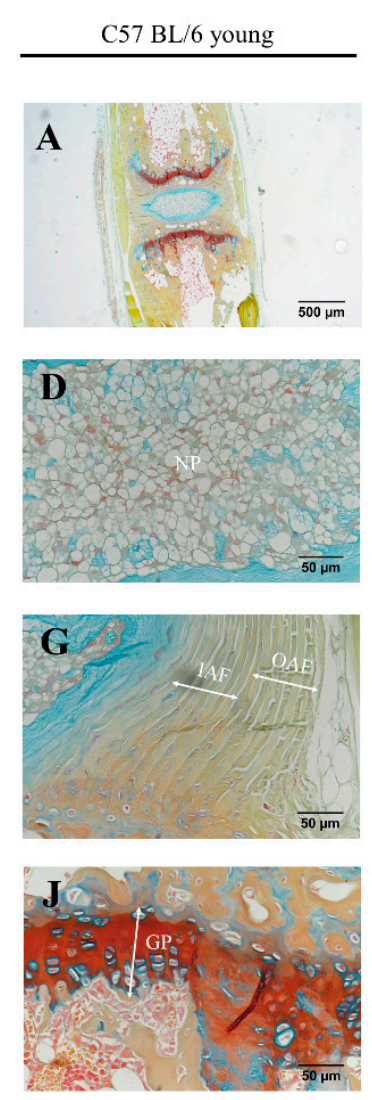

TRPV1 KO young
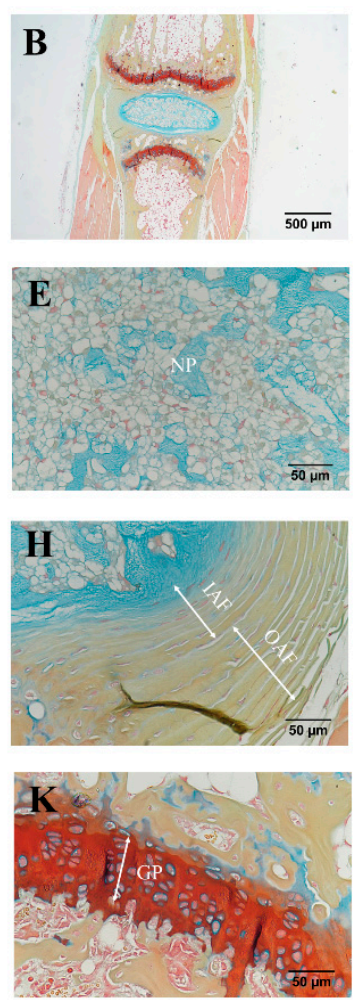

TRPV1 KO old
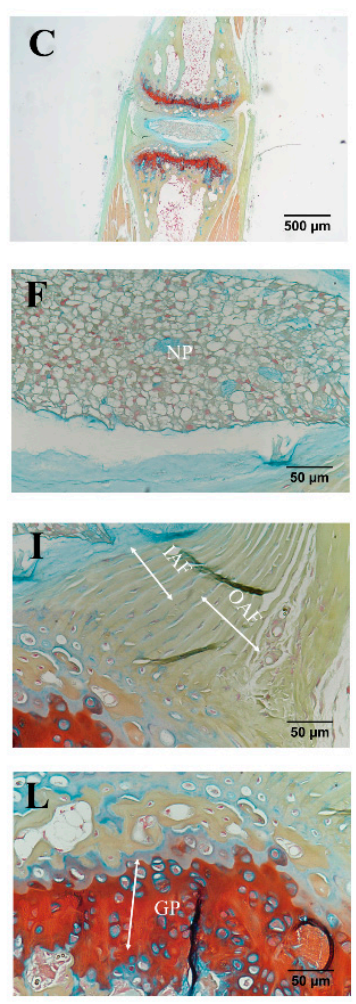

Figure 8. FAST staining of IVDs of TRPA1 WT and TRPV1 KO mice. The tail motion segments of C57 BL/6 young WT (A,D,G,J), TRPV1 young $\mathrm{KO}(\mathbf{B}, \mathbf{E}, \mathbf{H}, \mathbf{K})$, and TRPV1 old $\mathrm{KO}(\mathbf{C}, \mathbf{F}, \mathbf{I}, \mathbf{L})$ mice. The nucleus pulposus: NP (D-F); inner annulus fibrosus: IAF and outer annulus fibrosus: OAF (G-I); and, vertebral growth plate: GP $(J-L)$ are also shown in higher magnification. Scale bars indicate $500 \mu \mathrm{m}$ in upper panel (A-C), but $50 \mu \mathrm{m}$ in lower panels (D-L).

\section{Discussion}

Several TRP channels are expressed in joints and IVDs, but their potential biological function and therapeutic relevance are not fully understood. The first aim of this study was to investigate the expression of TRP channels in IVD cells in normal and inflammatory conditions, as inflammation is one of the major hallmarks of DDD. We showed that IL-1 $\beta$ significantly induced gene expression of TRPA 1 and TRPV4 and reduced TRPC6. TNF- $\alpha$ significantly increased the gene expression of TRPA1 and TRPV2, while reducing TRPV1. It was previously reported that TRPA1 and TRPV1 are commonly expressed in sensory neurons that can innervate joints and IVDs as well as in chondrocytes, where they are associated with degenerative changes $[24,27,28]$.

We found that gene expression of TRPA1 is undetectable in mature healthy human IVDs and untreated cultured IVD cells. Interestingly, TRPA1 was expressed in 20\% of degenerated IVDs, possibly due to the presence of pro-inflammatory cytokines. TRPA1 was also expressed in cells isolated from fetal disc tissue and in healthy juvenile samples, which pointed towards its involvement in disc development and/or maturation. FAST staining of tail motion segments of TRPA1 KO and TRPV1 KO mice suggested that TRPA1 might be involved in the homeostasis of GAG maintenance during the development of the IVD. Although these results corresponded to our findings in human IVD tissues/cells, they should be interpreted with caution, as differences between mice and human IVDs exist (e.g., the presence of notochordal cells in mice, degenerative status of mature mouse disc vs. human disc).

To evaluate the possible effects of TRPA1/TRPV1 activation in IVD cells, we used the TRPA1/TRPV1 agonist allyl isothiocyanate (AITC) [29]. AITC (or mustard oil) is commonly 
regarded as pro-inflammatory and nociceptive [30]. For example, TRPA1-deficient mice do not display acute pain-related behavior after the application of AITC to paws [31]. Our data indicated that the activation of TRPA1 may be the main mechanism for AITC-evoked increase in $\left[\mathrm{Ca}^{2+}\right]_{i}$ in IVD cells. In the non-inflamed IVD cells (expressing TRPV1), $10 \mu \mathrm{M}$ AITC stimulation was not associated with significant pro-inflammatory/catabolic effects, except for an increase in MMP1. In contrast, AITC-mediated regulation of gene expression of ADAMTS5, IL-8, and COL1A1 in cytokine-stimulated cells was likely to be TRPA1 dependent. The TRPA1 downstream effects may depend on agonist concentration, as previously shown by others [32,33] and in our study (reduced IL-8 in cells treated with $3 \mu \mathrm{M}$ AITC vs. upregulated IL-8 in in cells treated with $10 \mu \mathrm{M}$ AITC). The expression level of TRPA1 itself can be another reason for the observed differences in IL- 8 release between IL- $1 \beta$ and TNF- $\alpha$ treated cells (lower relative TRPA1 expression in IL-1 $\beta$-stimulated cells vs. TNF- $\alpha$-stimulated cells). The downregulation of COL1A1 and upregulation of IL-8 in TNF- $\alpha$, but not IL-1 $\beta$-treated cells, may be related to lower expression of TRPV1. Altogether, our data suggested that TRPA1 might be involved in the regulation of ECM homeostasis. However, major limitation of this study is low sample number, which prevents definite conclusions.

DDD is considered to be similar to chronic arthritis, due to the fact that common mechanisms are involved in the progression of both diseases [12]. Similar to our findings, the expression of TRPA1 in primary human osteoarthritic (OA) chondrocytes increased upon stimulation with IL-1 $\beta$, IL-17, LPS, and resistin [24]. Horvath et al. (2016) showed that the markers of chronic arthritis (chronic mechanical hypersensitivity, joint swelling, histopathological alterations, vascular leakage) were significantly reduced in TRPA1 KO mice (vs. wt), which indicated the involvement of TRPA1 in this disease [34]. A similar association of TRPV1 with chronic arthritis was previously demonstrated $[35,36]$. Interestingly, acute joint pain behaviors were not modified in TRPA1 KO mice [34]. The distinct roles of TRPA1 in chronic vs. acute arthritis could be attributed to a different distribution of TRPA1 (and possibly TRPV1) on sensory nerves and non-neuronal cells in these pathological conditions [34], e.g., due to the presence of pro-inflammatory cytokines. In this context, the modulation of inflammation itself can possibly regulate TRP channel activities (e.g., TRPV1 can be sensitized/desensitized by endogenous products of inflammation [37]). Importantly, pro-inflammatory cytokines (IL-1 $\beta$ and TNF- $\alpha$ ) can cause $\left[\mathrm{Ca}^{2+}\right]_{\mathrm{i}}$ increase in OA chondrocytes [34], but likely not in IVD cells [34], which might be related to differences in the TRP channel expression/activation/function in $\mathrm{OA}$ and DDD.

Chronic inflammation in both OA and DDD is associated with neuronal plasticity, which is an important mechanism in the development and maintenance of chronic pain [38]. Our current study did not employ an IVD degeneration/pain model, and thus it did not test the involvement of sensory neurons. Future studies will focus on the interplay between TRPA1/TRPV1 in inflamed IVD cells and DRG neurons, as well as on more specific activation/inhibition experiments by gene editing, both in vitro and in experimental animals.

Although TRPA1/TRPV1 antagonists/agonists have reached clinical trials for the treatment of inflammatory and neuropathic pain [39-41], discrepancies as to whether and how these channels contribute to the underlying mechanisms of inflammatory and neuropathic hypersensitivity can still be found in the literature [42]. Some endogenous ligands of TRPA1 might not yet be discovered and it is still unclear how physiological loading, which is an important parameter in IVD health, regulates the activity of TRPA1. It is likely that TRPA1 activation may be protective under certain circumstances and/or in particular cell types, possibly including the IVD. The protective anti-inflammatory effects of TRPA1 were recently demonstrated in mouse model of colitis [43], with TRPA1 KO mice having a significantly higher 'Disease Activity Index' and levels of pro-inflammatory neuropeptides and cytokines in the distal colon [43]. Another study showed that both the colonic and systemic administration of AITC and capsazepine (another TRPA1 agonist) induced a profound, body-wide TRPA1-mediated desensitization of nociception in mice [44]. The authors suggested that systemic 
desensitization through TRPA1 might provide a novel strategy for the medicinal treatment of various chronic inflammatory and pain states [44], which possibly included DDD.

Concerning other TRP channels that were regulated by an inflammatory environment in this study, increased TRPV4 expression/signaling in the IVD has been associated with decreased tissue osmolarity and the production of pro-inflammatory cytokines [17]. Our study provided evidence that IL-1 $\beta$ itself can regulate gene expression of TRPV4 in IVD cells., the Gene expression of TRPC6 was shown to be reduced in IVD cells under microgravity [18], but elevated in IVDs with increasing degeneration grade [19]. In our study, TRPC6 was downregulated by IL-1 $\beta$ treatment. To explain these inconsistencies and their pathophysiological relevance, the activity, stability, and subcellular localization of TRPC6 will be investigated in the future. Possibly, the activity of TRPC6 may be regulated by exocytosis [45], while cytoplasmic calcium may influence its expression and degradation [46,47], the levels of which are dysregulated in degenerated IVD cells [48]. To our knowledge, this is the first study that reported the downregulation of TRPV1 and upregulation of TRPV2 by TNF- $\alpha$ in IVD cells. The expression of TRPV2 was shown upregulated in inflamed DRGs [49], where it possibly participated in calcitonin gene-related peptide (CGRP) release [50].

\section{Materials and Methods}

\subsection{Subjects}

\subsubsection{Non-Degenerated Human IVD Tissue}

cDNA was synthesized from the non-degenerated human IVD cells, (gift provided by Prof. Lisbet Haglund from the Department of Surgery at McGill University, Canada), and prepared as previously described [51]. Informed consent for tissue collection was obtained from family members and the study was approved through the local ethics committee (A04-M53-08B).

\subsubsection{Human IVD Tissue}

25 human degenerated lumbar IVD samples were used for direct tissue analysis. These biopsies were obtained from 20 donors [mean age $=46.2$ years $(16-76$ years); nine male and eleven female] undergoing elective spinal surgery. IVD samples were intraoperatively separated into annulus fibrosus (AF, $n=11$ ) and nucleus pulposus (NP, $n=14$ ), followed by macroscopic tissue evaluation. The assessment of the disease state was performed using Pfirrmann and Modic grading. Demographic details are shown in Table 3-Tissue and [19]. An additional 30 lumbar degenerated IVDs, removed during surgeries for disc herniation (DH) or degenerative disc disease (DDD), were used for preparation of primary cell cultures. All of the biopsies were obtained with patient's informed consents. The Ethics Committee of Cantons Zurich and Lucerne approved the study (\#1007). Demographic details are shown in Table 3-Cells.

Table 3. Donors used for tissue and cell culture analyses. $\mathrm{DH}=$ herniation, $\mathrm{DDD}=$ degenerative disc disease, $\mathrm{AF}=$ annulus fibrosus, $\mathrm{NP}=$ nucleus pulposus, $\mathrm{uk}=$ unknown.

\begin{tabular}{cccccccc}
\hline \multicolumn{7}{c}{ Tissue } \\
\hline Donor & Age & Gender & Pathology & Tissue & Level & Grade & Experiments \\
\hline T1 & 30 & m & DDD & AF, NP & L4/5 & II & qPCR \\
\hline T2 & 46 & f & DH & AF, NP & L5/S1 & III & qPCR \\
\hline T3 & 34 & m & DH & AF, NP & L5/S1 & III & qPCR \\
\hline T4 & 46 & f & DH & AF, NP & L4-S1 & V & qPCR \\
\hline T5 & 59 & f & DDD & AF, NP & L5/S1 & V & qPCR \\
\hline T6 & 62 & f & DDD & AF & L5/S1 & V & qPCR \\
\hline T7 & 66 & f & DH & AF & L4/5 & II & qPCR \\
\hline T8 & 53 & m & DH & NP & L5/S1 & II & qPCR \\
\hline T9 & 59 & m & DH & NP & L4/L5 & II & qPCR \\
\hline
\end{tabular}


Table 3. Cont.

\begin{tabular}{|c|c|c|c|c|c|c|c|}
\hline \multicolumn{8}{|c|}{ Tissue } \\
\hline Donor & Age & Gender & Pathology & Tissue & Level & Grade & Experiments \\
\hline T10 & 52 & $\mathrm{~m}$ & DDD & $\mathrm{NP}$ & L4/L5 & III & qPCR \\
\hline T11 & 64 & $\mathrm{f}$ & DDD & $\mathrm{NP}$ & L4/L5 & IV & qPCR \\
\hline T12 & 76 & $\mathrm{f}$ & DH & $\mathrm{NP}$ & L4/L5 & III & qPCR \\
\hline $\mathrm{T} 13$ & 16 & $f$ & DH & $\mathrm{NP}$ & L4/L5 & III & qPCR \\
\hline T14 & 31 & $\mathrm{~m}$ & DDD & $\mathrm{AF}$ & $\begin{array}{c}\text { L4/5 } \\
\text { L5/S1 }\end{array}$ & IV & qPCR \\
\hline T15 & 54 & $f$ & $\mathrm{DH}$ & $\mathrm{NP}$ & $\mathrm{L} 5 / \mathrm{S} 1$ & II & qPCR \\
\hline T16 & 33 & $\mathrm{~m}$ & $\mathrm{DH}$ & $\mathrm{AF}$ & $\mathrm{L} 5 / \mathrm{S} 1$ & II & qPCR \\
\hline $\mathrm{T} 17$ & 70 & $f$ & DDD & $\mathrm{NP}$ & $\mathrm{L} 4 / 5$ & IV & qPCR \\
\hline T18 & 39 & $\mathrm{~m}$ & $\mathrm{DH}$ & $\mathrm{AF}$ & L5/S1 & III & qPCR \\
\hline T19 & 28 & $\mathrm{~m}$ & $\mathrm{DH}$ & $\mathrm{NP}$ & $\mathrm{L} 5 / \mathrm{S} 1$ & II & qPCR \\
\hline T20 & 21 & $\mathrm{f}$ & DDD & $\mathrm{AF}$ & $\mathrm{L} 4 / 5$ & III & qPCR \\
\hline \multicolumn{8}{|c|}{ Cells } \\
\hline Donor & Age & Gender & Pathology & Tissue & Level & Grade & Experiments \\
\hline $\mathrm{C} 1$ & 44 & F & uk & uk & L3/L4 & uk & qPCR \\
\hline $\mathrm{C} 2$ & 82 & $\mathrm{M}$ & uk & uk & $\mathrm{L} 5 / \mathrm{S} 1$ & uk & qPCR \\
\hline $\mathrm{C} 3$ & 28 & M & uk & uk & $\mathrm{L} 5 / \mathrm{S} 1$ & uk & qPCR \\
\hline C4 & uk & uk & uk & uk & uk & uk & qPCR, ELISA \\
\hline $\mathrm{C} 5$ & uk & uk & uk & uk & uk & uk & qPCR, ELISA \\
\hline C6 & 39 & $\mathrm{M}$ & DDD, DH & Mix & L4/L5 & IV & ELISA \\
\hline C7 & 58 & M & DDD, DH & Mix & $\mathrm{L} 5 / \mathrm{S} 1$ & IV & qPCR, ELISA \\
\hline $\mathrm{C} 8$ & 46 & F & DH & - & $\mathrm{L} 5 / \mathrm{S} 1$ & IV & qPCR, ELISA \\
\hline C9 & 52 & $\mathrm{M}$ & DDD, DH & Mix & $\mathrm{L} 5 / \mathrm{S} 1$ & $\mathrm{~V}$ & qPCR, ELISA \\
\hline $\mathrm{C} 10$ & 46 & F & $\mathrm{DDD}, \mathrm{DH}$ & Mix & L4/L5 & IV & qPCR, Ca imaging \\
\hline $\mathrm{C} 11$ & 58 & M & uk & Mix & L4/L5 & IV & Ca imaging \\
\hline $\mathrm{C} 12$ & 31 & $\mathrm{M}$ & DDD, DH & Mix & $\mathrm{L} 5 / \mathrm{S} 1$ & IV & qPCR \\
\hline $\mathrm{C} 13$ & 46 & $\mathrm{M}$ & $\mathrm{DH}$ & Mix & C5/C6 & III & qPCR \\
\hline C14 & 40 & $\mathrm{~F}$ & DH & Mix & L4/L5 & III & qPCR \\
\hline C15 & 40 & $\mathrm{M}$ & DH & $\mathrm{NP}$ & L4/L5 & III & qPCR \\
\hline $\mathrm{C} 16$ & 66 & F & $\mathrm{DH}$ & $\mathrm{NP}$ & L4/L5 & III & Ca imaging \\
\hline $\mathrm{C} 17$ & uk & uk & uk & uk & uk & uk & qPCR, ELISA \\
\hline $\mathrm{C} 18$ & 50 & F & $\mathrm{DH}$ & Mix & $\mathrm{L} 5 / \mathrm{S} 1$ & IV & qPCR \\
\hline C19 & 42 & M & DH & Mix & L5/S1 & $\mathrm{V}$ & qPCR \\
\hline $\mathrm{C} 20$ & 68 & $\mathrm{~F}$ & listhesis & Mix & L4/L5 & III & qPCR \\
\hline $\mathrm{C} 21$ & 38 & $\mathrm{M}$ & DH & Mix & $\mathrm{L} 5 / \mathrm{S} 1$ & III & qPCR, ELISA \\
\hline $\mathrm{C} 22$ & 41 & $\mathrm{~F}$ & $\mathrm{DH}$ & Mix & $\mathrm{L} 4 / 5$ & III & qPCR, ELISA \\
\hline $\mathrm{C} 23$ & 42 & M & DH & NP & L5/S1 & IV & qPCR, ELISA \\
\hline $\mathrm{C} 24$ & 41 & $\mathrm{~F}$ & $\mathrm{DH}$ & Mix & $\mathrm{L} 5 / \mathrm{S} 1$ & III & qPCR, ELISA \\
\hline $\mathrm{C} 25$ & 45 & M & $\mathrm{DH}$ & $\mathrm{NP}$ & L4/L5 & IV & qPCR, ELISA \\
\hline $\mathrm{C} 26$ & 71 & uk & DDD & Mix & $\mathrm{L} 4 / 5$ & III & qPCR, ELISA \\
\hline $\mathrm{C} 27$ & 55 & $\mathrm{~F}$ & $\mathrm{DH}$ & $\mathrm{NP}$ & $\mathrm{L} 5 / 6$ & I & qPCR, ELISA \\
\hline $\mathrm{C} 28$ & 55 & $\mathrm{~F}$ & DH & $\mathrm{NP}$ & L5/6 & II & Immuno \\
\hline $\mathrm{C} 29$ & 55 & M & $\mathrm{DH}$ & Mix & $\mathrm{L} 5 / \mathrm{S} 1$ & II & Immuno \\
\hline C 30 & 58 & M & DH & Mix & $\mathrm{L} 4 / 5$ & IV & Immuno \\
\hline $\mathrm{C} 31$ & 34 & M & - & $\mathrm{NP}, \mathrm{AF}$ & L1/2-L2 & 3-L3/4 4 & qPCR \\
\hline $\mathrm{C} 32$ & 55 & F & - & $\mathrm{NP}, \mathrm{AF}$ & $\mathrm{L} 1 / 2$ & III & qPCR \\
\hline C33 & 52 & $\mathrm{M}$ & - & $\mathrm{NP}$ & L1-L5 & I & qPCR \\
\hline C34 & 17 & $\mathrm{M}$ & - & $\mathrm{NP}$ & T12-S1 & I & qPCR \\
\hline LC1 & 16 & $\mathrm{M}$ & - & $\operatorname{mix}$ & uk & II & qPCR \\
\hline LFC2 & \multicolumn{6}{|c|}{ Fetal IVD cells, Male, 16 weeks: p5 } & qPCR \\
\hline LFC3 & \multicolumn{6}{|c|}{ Fetal IVD cells, Male, 14 weeks: p4 } & qPCR \\
\hline LFC4 & \multicolumn{6}{|c|}{ Fetal IVD cells, Male, 14 weeks: p4 } & qPCR \\
\hline
\end{tabular}




\subsubsection{Human Fetal IVD Cells}

The cell cultures were derived from biopsies that were obtained in accordance with the Ethics Committee of the University Hospital of Lausanne (Ethics Protocol 51/01) and following the Federal Transplantation Program guidelines. The cell banks are managed in the Department Biobank following the regulations of the Biobank for clinical research for both the fetal and adult tissue. Specific biopsies consisting of a spinal unit of three vertebra and two discs representing tissue of $6.5 \mathrm{~mm} \times 5 \mathrm{~mm}$ in size were obtained from fetal tissue following the voluntary interruption of pregnancy at 14-16 weeks of gestation. Biopsies were first rinsed in $1 \%$ penicillin/strepotomycin in phosphate buffer saline (PBS) and adjacent soft tissue that was delicately dissected from the main disc tissue. We thereafter prepared one IVD and two adjacent vertebrae from a fetal spine unit; primary cultures used Dulbecco's Modified Eagle's medium (DMEM) (41966-029, Gibco, Waltham, MA, USA) that was supplemented with $10 \%$ fetal bovine serum and $100 \mathrm{mM}$ L-Glutamine (25030-024, Gibco). Culture conditions were at $37^{\circ} \mathrm{C}$ under $5 \% \mathrm{CO}_{2}$. One juvenile patient was also used. Cell cultures from the juvenile patient following discectomy were established as above, except type II collagenase digestion, was implemented. Cells were expanded and stored frozen in liquid nitrogen at passage 1 or 2 and the cells were thawed, expanded in monolayer at passage 3, and used for analysis following passage 4 . Table 3 shows donor details.

\subsubsection{Knock-Out Mice}

Tails from C57BL/ 6 TRPA1 wild-type (WT) and knock out (KO) mice and 15 TRPV1 WT and KO mice were used (Table 4). The mice were divided into two groups: young (two, four months old) and mature (seven months old) and euthanized in the context of other research activities. C57BL/ 6 mice were use as control for TRPV1 KO as this strain was backcrossed $10 \times$ to the C57BL/ 6 background. Immediately after euthanasia with pentobarbital (100 mg/kg i.p.), the tails were dissected, skinned, rinsed in PBS, and fixed in 4\% paraformaldehyde solution (Szkarabeusz Kft., Pecs, Hungary) in $0.1 \mathrm{M}$ phosphate buffer. After two days, the fixed tails were washed with PBS and then placed into $10 \%$ EDTA (E6758, Sigma, St. Louis, MO, USA) exchanged every two days. After 10 days, the decalcified samples were washed in PBS and placed into $70 \%$ ethanol (51976, Sigma) at $4{ }^{\circ} \mathrm{C}$ until paraffin embedding. Paraffin blocks were then used to prepare $5 \mu \mathrm{m}$ sections.

Table 4. Mouse spines used for FAST staining.

\begin{tabular}{cccc}
\hline Mice & 2 Months Old & 4 Months Old & 7 Months Old \\
\hline TRPA1 WT & $n=5$ & - & $n=5$ \\
\hline TRPA1 KO & $n=5$ & - & $n=5$ \\
\hline TRPV1 KO & - & $n=5$ & $n=5$ \\
\hline C57BL/6 & - & $n=5$ & - \\
\hline
\end{tabular}

\subsection{Cell Culture}

\subsubsection{D Cell Culture}

IVD tissue was diced to around $1 \mathrm{~mm}^{3}$ pieces and treated with a mixture of $0.3 \%$ dispase (04942078001, Roche Diagnostics, Mannheim, Germany) and 0.2\% collagenase (17454, SERVA Electrophoresis, Heidelberg, Germany) in PBS at $37{ }^{\circ} \mathrm{C}$ for $4-8 \mathrm{~h}$ to isolate the cells. After the incubation, the suspension was filtered through a $70 \mu \mathrm{m}$ cell strainer $(542070$, Greiner Bio-One, Kremsmünster, Austria), centrifuged at $700 \times g$ for $5 \mathrm{~min}$, and resuspended in DMEM/F12 (31330-038, Thermo Fisher Scientific, Waltham, MA, USA) supplemented with $10 \%$ fetal calf serum (FCS, F7524, Merck, Darmstadt, Germany), 100 units/mL penicillin, $100 \mu \mathrm{g} / \mathrm{mL}$ streptomycin, and $250 \mathrm{ng} / \mathrm{mL}$ amphotericin B (15240-062, Gibco, Carlsbad, CA, USA). The primary IVD cells were 
expanded in monolayer in a standard cell culture incubator $\left(5 \% \mathrm{CO}_{2}, 37^{\circ} \mathrm{C}\right)$ up to passage 3 before being used in the experiments.

\subsubsection{D Cell Culture}

The IVD cells were detached using 1.5\% trypsin (15090-046, Thermo Fisher Scientific) and seeded in $1.2 \%$ alginate (71238-50G, Sigma, St. Louis, MO, USA) at a density of $4 \times 10^{6}$ IVD cells per $1 \mathrm{~mL}$ alginate, as described previously [52]. Briefly, the cells-alginate mixture was dropped into $102 \mathrm{mM}$ calcium chloride solution (1.02382, Merck) while using a sterile syringe and needle and left for $8 \mathrm{~min}$ to polymerize under gentle stirring until beads were formed. After washing with $0.9 \% \mathrm{NaCl}$ (1.06404, Merck) and PBS $(3 \times 1 \mathrm{~min})$, the beads were transferred into six well plates and pre-cultured for seven days.

\subsubsection{Cell Viability of 3D Cell Culture}

Cell viability in the alginate beads was tested using calcein/ethidium homodimer staining. Staining solution was prepared by mixing culture media with $2 \mu \mathrm{M}$ ethidium homodimer (46043, Sigma) and $2 \mu$ M calcein-AM (17783, Sigma). $200 \mu \mathrm{L} /$ well of the staining solution was added into a 96-well plate containing beads (one bead per culture condition per well) and then incubated for $30 \mathrm{~min}$. Subsequently, the beads were gently squeezed between cover slips and three photos were randomly captured with a fluorescence microscope (Olympus IX51, Tokyo, Japan) at the wavelength of $515 \mathrm{~nm}$ (calcein: living cells) and $620 \mathrm{~nm}$ (ethidium: dead cells). The cell numbers in each image were counted by ImageJ ver.1.51j8 and averaged. Cell viability is shown as the number of living cells per total cells.

\subsection{Treatments}

\subsubsection{D Cell Cultures}

Table 5 shows all treatments. Experiments were conducted in culture media without antibiotics and FCS (= experimental media). For gene expression analysis and ELISA, the IVD cells were seeded into T25 flasks $\left(3.5 \times 10^{5}\right.$ cells/flask) or six-well plates $\left(3 \times 10^{5}\right.$ cells/well). For immunofluorescence, $1 \times 10^{5}$ cells were seeded into the wells of chambered slides (155380, Thermo Fisher Scientific). For Calcium imaging, the $4 \times 10^{4}$ cells were seeded into 96-well plates in triplicates and incubated for $18 \mathrm{~h}$. The next day, complete media was changed to the experimental media. After $2 \mathrm{~h}$ in experimental media, the cells were exposed to 5 or $10 \mathrm{ng} / \mathrm{mL}$ recombinant TNF- $\alpha$ (315-01A, PeproTech, Umkirch, Germany) or IL-1 $\beta$ (200-01B, PeproTech) for $18 \mathrm{~h}$. Non-stimulated cells were used as the controls. To investigate the effects of TRPA1 and TRPV1 activation, 3 and $10 \mu \mathrm{M}$ allyl isothiocyanate (AITC, TRPA1 agonist, 377430 , Sigma) was used either in untreated cells or in IL1- $\beta$ and TNF- $\alpha$ treated cells (focus on TRPA1, whose expression is increased in an inflammatory environment). The EC50 value for AITC that is reported in the literature is approximately $3 \mu \mathrm{M}$, while AITC concentrations higher than $10 \mu \mathrm{M}$ may cause channel desensitization [32,33].

\subsubsection{D Cell Cultures}

The experiments were conducted in culture media without antibiotics and with FCS. On day 7, cells in alginate beads were stimulated with $5 \mathrm{ng} / \mathrm{mL} \mathrm{IL-} \beta$ and collected after $24 \mathrm{~h}$ (day 1), eight days (day 8), and 15 days (day 15) (Table 5). Culture media for the latter group was exchanged on day 8 , with new $5 \mathrm{ng} / \mathrm{mL}$ IL-1 $\beta$. At the end of the experiment, the cells were liberated from the beads in $1.9 \mathrm{~mL}$ of $55 \mathrm{mM}$ sodium citrate solution (71406, Sigma) and centrifuged at $700 \times g$ for $5 \mathrm{~min}$. Cell pellets were used for subsequent analyses. 
Table 5. Details of cell culture treatments.

\begin{tabular}{|c|c|c|c|c|c|}
\hline Compound & Catalog Number & Function & Concentration & Exposure Time & Experiment \\
\hline TNF- $\alpha$ & 315-01A PeproTech & Inflammatory cytokine & $5,10 \mathrm{ng} / \mathrm{mL}$ & $18 \mathrm{~h}$ & qPCR Ca imaging \\
\hline \multirow{3}{*}{ IL-1 $\beta$} & \multirow{3}{*}{ 200-01B PeproTech } & \multirow{3}{*}{ Inflammatory cytokine } & $5,10 \mathrm{ng} / \mathrm{mL}$ & $18 \mathrm{~h}$ & qPCR Ca imaging \\
\hline & & & $5 \mathrm{ng} / \mathrm{mL}$ & $1,8,15$ days & qPCR (from 3D) \\
\hline & & & $5 \mathrm{ng} / \mathrm{mL}$ & $18 \mathrm{~h}$ & Immuno \\
\hline \multirow{2}{*}{ AITC } & \multirow{2}{*}{377430 Sigma } & \multirow{2}{*}{ TRPA1 agonist } & $3 \mu \mathrm{M}, 10 \mu \mathrm{M}$ & $18 \mathrm{~h}$ & qPCR, ELISA \\
\hline & & & $100 \mu \mathrm{M}$ & during the measurement & Ca imaging \\
\hline
\end{tabular}

\subsection{Analyses}

\subsubsection{Gene Expression Analysis of IVD Tissue}

RNA extraction from IVD tissue and the following steps were performed according to [19]. For cDNA synthesis, two micrograms of RNA were used in a total volume of $60 \mu \mathrm{L}$, while using the reverse transcription kit (4374966, Applied Biosystems, Foster City, CA, USA). For samples with lower yields, the reverse transcription was conducted at reduced concentrations. cDNA (10 ng/well) was mixed with TaqMan Fast Universal PCR Master Mix and TaqMan primers (Table 6) to quantify gene expression. The obtained $C_{\mathrm{t}}$ values were analyzed by a comparative method and displayed as $2^{-\mathrm{dCt}}$ values, with GAPDH as housekeeping gene.

\subsubsection{FAST Staining}

To study the glycosaminoglycan (GAG) contents in IVD, a multi-dye histological staining using Fast green, Alcian blue, Saffranin-O, and tartrazine was performed on IVD tissue sections accordingly [53]. In brief, parafilm embedded tissue sections were first dewaxed in xylene and then rehydrated in a stepwise gradient of ethanol. The IVD sections were first stained with $1 \%$ Alcian blue 8GX (A3157, Sigma) pH 1.0 for $1 \mathrm{~min}$, followed by 0.1\% Saffranin-O (S8884, Sigma) for $3 \mathrm{~min}$. Saffranin-O reddish colour differentiation was performed in $25 \%$ ethanol for $15 \mathrm{~s}$. The tissue sections were then stained in $0.08 \%$ Tartrazine (T0388, Sigma) with $0.25 \%$ acetic acid for $45 \mathrm{~s}$ and finally counterstained by $0.01 \%$ Fast green (F7258, Sigma) solution for $5 \mathrm{~min}$. Sections were finally air-dried, mounted in DePeX (BDH Laboratory; Poole, UK), and examined under a Nikon Eclipse 80i microscope (Tokyo, Japan).

\subsubsection{Gene Expression Analysis of IVD Cells}

RT-qPCR was performed to analyze the expression of target genes (Table 6). The cells were lysed with $1 \mathrm{~mL}$ Trizol (Genezol, GZR200, Geneaid biotech, New Taipei City, Taiwan) and RNA was isolated according to the manufacturer's recommendations. Briefly, after adding chloroform (132950, Sigma), the samples were mixed well for $15 \mathrm{~s}$, left for $5 \mathrm{~min}$ at RT, and centrifuged $(12,000 \times g$ for $15 \mathrm{~min}$ ). Supernatants were carefully transferred to new RNase free tubes, $500 \mu \mathrm{L}$ of isopropanol (20842, VWR chemicals, Fontenay-sous-Bois, France) was added and mixed well. After 5 min, the samples were centrifuged again $(12,000 \times g$ for $15 \mathrm{~min})$. The pellets were washed with $75 \%$ ethanol (1.00983, Merck) at $7500 \times g$ for $5 \mathrm{~min}$ and then dissolved in RNase free water (10977, Invitrogen, Carlsbad, CA, USA). The purity and concentration of the resulting RNA were measured using the NanoDrop (ND-1000, Thermo Fisher Scientific). $1 \mu \mathrm{g}$ of total RNA was reverse-transcribed to cDNA using a reverse transcription kit (4374966, Applied Biosystems, Foster City, CA, USA). qPCR of the mixture of primers/probes (Table 6) and master mix (4367846, Applied Biosystems) was performed on the CFX96 Real-Time System (Bio-Rad Laboratories, Hercules, CA, USA). The amplification program was as follows: heating at $95^{\circ} \mathrm{C}$ for $10 \mathrm{~min} ; 40$ cycles of $95^{\circ} \mathrm{C}$ for $1 \mathrm{~s}$ and $60^{\circ} \mathrm{C}$ for $20 \mathrm{~s}$. The relative expression level was calculated by the $\mathrm{dd} C_{\mathrm{t}}$ method. For normalization purposes, the samples with undetectable expression were assigned $C_{\mathrm{t}}$ value 40 . The results are shown as fold change, relative to control or relative to cytokine treatment. 
Table 6. Target genes and assay identification (ID) numbers of corresponding TaqMan primers (TaqMan Gene Expression Assays; Thermo Fisher Scientific). TRP = transient receptor potential; $\mathrm{MMP}=$ matrix metalloproteinase; TIMP = tissue inhibitor of matrix metalloproteinase; ADAMTS $=$ a disintegrin and metalloproteinase with thrombospondin motifs; COX-2 = cyclooxygenase-2; NGF = nerve growth factor. IL-6 = interleukin 6; IL-8 = interleukin 8; HKG = housekeeping gene.

\begin{tabular}{|c|c|c|}
\hline Target Gene & Assay ID & Putative Association with Inflammation \\
\hline TBP & Hs00427620_m1 & HKG in the cell culture study and fetal cells \\
\hline GAPDH & Hs02758991_g1 & HKG in the tissue study \\
\hline TRPA1 & Hs00175798_m1 & inflammatory pain [12] \\
\hline TRPC1 & Hs00608195_m1 & bladder inflammation (neuronal) [54] \\
\hline TRPC3 & Hs00162985_m1 & inflammatory pain [55] \\
\hline TRPC6 & Hs00988479_m1 & IVD inflammation (putative) $[18,19]$ \\
\hline TRPV1 & Hs00218912_m1 & neuroinflammation [20] \\
\hline TRPV2 & Hs00901648_m1 & inflammation in DRG [49] \\
\hline TRPV4 & Hs01099348_m1 & lung inflammation [56] \\
\hline TRPV6 & Hs00367960_m1 & association with TNF- $\alpha$ [57] \\
\hline TRPM2 & Hs01066091_m1 & inflammatory and neuropathic pain [58] \\
\hline TRPM7 & Hs00559080_m1 & inflammation in colitis [59] \\
\hline IL-6 & Hs00174131_m1 & inflammation mediator [60] \\
\hline IL-8 & Hs00174103_m1 & inflammation mediator [60] \\
\hline MMP1 & Hs00233958_m1 & cleaves mainly collagens (I, II, III) [61] \\
\hline MMP3 & Hs00968305_m1 & cleaves proteoglycans and collagens (II, III) [61] \\
\hline ADAMTS4 & Hs00192708_m1 & cleaves mainly aggrecan [61] \\
\hline ADAMTS5 & Hs01095518_m1 & cleaves mainly aggrecan [61] \\
\hline TIMP1 & Hs00234278_m1 & inhibits MMPs $(1,3)$ and ADAMTS (4) [61] \\
\hline TIMP2 & Hs01092512_g1 & inhibits all MMPs [61] \\
\hline COX-2 & Hs00153133_m1 & pain mediator [62] \\
\hline NGF & Hs00171458_m1 & nerve ingrowth [38] \\
\hline COL2A1 & Hs00264051_m1 & ECM constituent \\
\hline COL1A1 & Hs00164004_m1 & ECM constituent \\
\hline Aggrecan & Hs00153936_m1 & ECM constituent \\
\hline
\end{tabular}

\subsubsection{Immunofluorescence}

The cells were seeded into the wells of chambered slides, washed with PBS, fixed with ice cold methanol (10 min), and blocked with 5\% normal goat serum in PBS (1 h at RT). A primary antibody recognizing the N-terminus of the human TRPA1 protein (NB110-40763, Novus Biologicals) was diluted in 1\% normal goat serum in PBS (1:200) (G9023, Sigma) and applied 1h under agitation at RT. Cells without primary antibody were used as immunospecificity control. After washing with PBS $(3 \times 5 \mathrm{~min})$, a secondary antibody that was diluted in $1 \%$ normal goat serum (1:200) (Cy2 anti-rabbit IgG, 111-225-144, Jackson Immuno Research) was applied for $1 \mathrm{~h}$ at RT under agitation. Next, cells were washed with PBS ( $3 \times 5 \mathrm{~min})$, coverslipped with 1-2 drops of antifade mounting medium with DAPI (VECTASHIELD; H-1200), and imaged with a fluorescence microscope (Olympus IX51). 


\subsubsection{Enzyme-Linked Immunosorbent Assay (ELISA)}

To quantify the release of inflammatory markers from IVD cells, the cell culture medium was collected and analyzed with IL-6 and IL-8 ELISA kit, according to the manufacturer's protocol (IL-6 555220, IL-8 555244, BD Biosciences, San Jose, CA, USA). 96-well plates were coated with capture antibody overnight. After washing, the wells were blocked in assay diluent, washed, loaded with samples or human recombinant IL- 6 or IL-8 protein standards, and incubated for $2 \mathrm{~h}$ at RT. After washing, detection antibody and streptavidin-horseradish peroxidase (HRP) were applied for $1 \mathrm{~h}$. Next, the plates were washed and substrate solution was added. After $30 \mathrm{~min}$, the reaction was stopped by kit stop solution and the absorbance was measured at $450 \mathrm{~nm}$, with $570 \mathrm{~nm}$ correction. The IL- 6 and IL- 8 concentrations were calculated based on the standard curve. IL- 6 and IL- 8 in culture media are shown relative to the cytokine treatment.

\subsection{6. $\left[\mathrm{Ca}^{2+}\right]_{\mathrm{i}}$ Imaging}

Fura-2 QBT $^{\mathrm{TM}}$ Calcium Kit was used to measure the increase in intracellular calcium (R8197, Molecular Devises, San Jose, CA, USA). Briefly, culture media was replaced with Fura-2-AM kit solution and the cells were incubated for $1 \mathrm{~h}$. Basal Fura-2 fluorescence was recorded for 5 min using a plate reader (infinite M200 pro, Tecan, Männedorf, Switzerland) at an excitation wavelength of 340 and $380 \mathrm{~nm}$ and an emission wavelength of $510 \mathrm{~nm}$. After five cycles, the cells were exposed in $100 \mu \mathrm{M}$ of AITC (to activate disc cells within a short timeline) and the measurement was continued. Ionomycin (13909, Sigma) was used as a positive control for channel stimulation. Data is shown as the ratio of $340 / 380$ wavelengths.

\subsubsection{Statistical Analysis}

Statistical analysis was performed in GraphPad Prism 8.0.0. Groups were compared using the Kruskal-Wallis nonparametric test followed by Dunn's multiple comparison test. Data is shown as mean \pm SD. $p<0.05$ was considered to be statistically significant $\left({ }^{*} p<0.05,{ }^{* *} p<0.01, * * * p<0.001\right)$.

\section{Conclusions}

To our knowledge, this is the first study that demonstrated a cytokine-dependent increase in the gene expression of TRPA1, TRPV2, and TRPV4 and a decrease in the gene expression of TRPC6 and TRPV1 in human IVD cells. Although TRPA1 and TRPV1 are commonly associated with inflammatory pain, their activation in inflamed IVD cells did not have profound pro-inflammatory and catabolic effects. Instead, TRPA1 expression and activation was associated with ECM metabolism. Future studies will use targeted gene editing techniques to elucidate the exact role of TRPA1/TRPV1 in DDD.

Supplementary Materials: Supplementary materials can be found at http://www.mdpi.com/1422-0067/20/7/ $1767 /$ s1.

Author Contributions: T.K. performed cell culture experiments, calcium flux analysis and drafted part of the manuscript. J.Z. performed cell culture experiments. M.V. performed cell culture experiments. A.S. performed tissue analyses. W.K.T. and V.Y.L. performed and evaluated FAST staining. K.B. and Z.H. secured the mouse experiments. L.A.A. provided fetal IVD cell lysates. O.N.H. and J.K. provided human IVD samples and clinical expertise. O.K. performed cell culture experiments, supervised the study and drafted parts of the manuscript. K.W.-K. supervised the study and conceived funding. The authors declare no conflict of interest.

Acknowledgments: This study was funded by the Swiss National Science Foundation (SNF PP00P2_163678/1), the Spine Society of Europe (Eurospine 2016_4), and Hungarian grants GINOP-2.3.2.-15-2016-00048 "Stay Alive" and EFOP 3.6.2. "Live longer". We thank H. Greutert for technical assistance in the study.

Conflicts of Interest: The authors declare no conflict of interest. 


\section{References}

1. Pai, S.; Sundaram, L.J. Low back pain: An economic assessment in the United States. Orthop. Clin. N. Am. 2004, 35, 1-5. [CrossRef]

2. Ito, K.; Creemers, L. Mechanisms of intervertebral disk degeneration/injury and pain: A review. Glob. Spine J. 2013, 3, 145-152. [CrossRef] [PubMed]

3. Wuertz, K.; Vo, N.; Kletsas, D.; Boos, N. Inflammatory and catabolic signalling in intervertebral discs: The roles of NF-kappaB and MAP kinases. Eur. Cell. Mater. 2012, 23, 103-119. [CrossRef] [PubMed]

4. Vo, N.V.; Hartman, R.A.; Patil, P.R.; Risbud, M.V.; Kletsas, D.; Iatridis, J.C.; Hoyland, J.A.; Le Maitre, C.L.; Sowa, G.A.; Kang, J.D. Molecular mechanisms of biological aging in intervertebral discs. J. Orthop. Res. 2016, 34, 1289-1306. [CrossRef]

5. Johnson, Z.I.; Schoepflin, Z.R.; Choi, H.; Shapiro, I.M.; Risbud, M.V. Disc in Flames: Roles of Tnf-alpha AND IL-1 beta in Intervertebral Disc Degeneration. Eur. Cell. Mater. 2015, 30, 104-117. [CrossRef]

6. Zhang, J.M.; An, J. Cytokines, inflammation, and pain. Int. Anesthesiol. Clin. 2007, 45, 27-37. [CrossRef]

7. Kepler, C.K.; Markova, D.Z.; Hilibrand, A.S.; Vaccaro, A.R.; Risbud, M.V.; Albert, T.J.; Anderson, D.G. Substance P stimulates production of inflammatory cytokines in human disc cells. Spine 2013, 38, E1291-E1299. [CrossRef] [PubMed]

8. Freemont, A.J.; Peacock, T.E.; Goupille, P.; Hoyland, J.A.; OBrien, J.; Jayson, M.I.V. Nerve ingrowth into diseased intervertebral disc in chronic back pain. Lancet 1997, 350, 178-181. [CrossRef]

9. Stemkowski, P.L.; Noh, M.C.; Chen, Y.S.; Smith, P.A. Increased excitability of medium-sized dorsal root ganglion neurons by prolonged interleukin-1 exposure is $\mathrm{K}^{+}$channel dependent and reversible. J. Physiol. 2015, 593, 3739-3755. [CrossRef]

10. Wilkinson, M.F.; Earle, M.L.; Triggle, C.R.; Barnes, S. Interleukin-1beta, tumor necrosis factor-alpha, and LPS enhance calcium channel current in isolated vascular smooth muscle cells of rat tail artery. FASEB J. 1996, 10, 785-791. [CrossRef]

11. Gavenis, K.; Schumacher, C.; Schneider, U.; Eisfeld, J.; Mollenhauer, J.; Schmidt-Rohlfing, B. Expression of ion channels of the TRP family in articular chondrocytes from osteoarthritic patients: Changes between native and in vitro propagated chondrocytes. Mol. Cell. Biochem. 2009, 321, 135-143. [CrossRef] [PubMed]

12. Krupkova, O.; Zvick, J.; Wuertz-Kozak, K. The role of transient receptor potential channels in joint diseases. Eur. Cell. Mater. 2017, 34, 180-201. [CrossRef] [PubMed]

13. Patapoutian, A.; Tate, S.; Woolf, C.J. Transient receptor potential channels: Targeting pain at the source. Nat. Rev. Drug Discov. 2009, 8, 55-68. [CrossRef]

14. Wu, L.J.; Sweet, T.B.; Clapham, D.E. International Union of Basic and Clinical Pharmacology. LXXVI. Current progress in the mammalian TRP ion channel family. Pharmacol. Rev. 2010, 62, 381-404. [CrossRef]

15. Gees, M.; Colsoul, B.; Nilius, B. The Role of Transient Receptor Potential Cation Channels in Ca ${ }^{2+}$ Signaling. Cold Spring Harb. Perspect. Biol. 2010, 2, a003962. [CrossRef] [PubMed]

16. Montell, C.; Birnbaumer, L.; Flockerzi, V.; Bindels, R.J.; Brudorf, E.A.; Caterina, M.J.; Clapham, D.E.; Harteneck, C.; Heller, S.; Julius, D.; et al. A unified nomenclature for the superfamily of TRP cation channels. Mol. Cell 2002, 9, 229-231. [CrossRef]

17. Walter, B.A.; Purmessur, D.; Moon, A.; Occhiogrosso, J.; Laudier, D.M.; Hecht, A.C.; Iatridis, J.C. Reduced tissue osmolarity increases TRPV4 expression and pro-inflammatory cytokines in intervertebral disc cells. Eur. Cell. Mater. 2016, 32, 123-136. [CrossRef]

18. Franco-Obregon, A.; Cambria, E.; Greutert, H.; Wernas, T.; Hitzl, W.; Egli, M.; Sekiguchi, M.; Boos, N.; Hausmann, O.; Ferguson, S.J.; et al. TRPC6 in simulated microgravity of intervertebral disc cells. Eur. Spine J. 2018, 27, 2621-2630. [CrossRef]

19. Sadowska, A.; Touli, E.; Hitzl, W.; Greutert, H.; Ferguson, S.J.; Wuertz-Kozak, K.; Hausmann, O.N. Inflammaging in cervical and lumbar degenerated intervertebral discs: Analysis of proinflammatory cytokine and TRP channel expression. Eur. Spine J. 2018, 27, 564-577. [CrossRef]

20. Marrone, M.C.; Morabito, A.; Giustizieri, M.; Chiurchiu, V.; Leuti, A.; Mattioli, M.; Marinelli, S.; Riganti, L.; Lombardi, M.; Murana, E.; et al. TRPV1 channels are critical brain inflammation detectors and neuropathic pain biomarkers in mice. Nat. Commun. 2017, 8, 15292. [CrossRef]

21. Fernandes, E.S.; Fernandes, M.A.; Keeble, J.E. The functions of TRPA1 and TRPV1: Moving away from sensory nerves. Br. J. Pharmacol. 2012, 166, 510-521. [CrossRef] 
22. Kelly, S.; Chapman, R.J.; Woodhams, S.; Sagar, D.R.; Turner, J.; Burston, J.J.; Bullock, C.; Paton, K.; Huang, J.; Wong, A.; et al. Increased function of pronociceptive TRPV1 at the level of the joint in a rat model of osteoarthritis pain. Ann. Rheum. Dis. 2015, 74, 252-259. [CrossRef]

23. Yu, L.; Yang, F.; Luo, H.; Liu, F.Y.; Han, J.S.; Xing, G.G.; Wan, Y. The role of TRPV1 in different subtypes of dorsal root ganglion neurons in rat chronic inflammatory nociception induced by complete Freund's adjuvant. Mol. Pain 2008, 4, 61. [CrossRef]

24. Nummenmaa, E.; Hamalainen, M.; Moilanen, L.J.; Paukkeri, E.L.; Nieminen, R.M.; Moilanen, T.; Vuolteenaho, K.; Moilanen, E. Transient receptor potential ankyrin 1 (TRPA1) is functionally expressed in primary human osteoarthritic chondrocytes. Arthr. Res. Ther. 2016, 18, 185. [CrossRef]

25. Gouin, O.; L'Herondelle, K.; Lebonvallet, N.; Le Gall-Ianotto, C.; Sakka, M.; Buhe, V.; Plee-Gautier, E.; Carre, J.L.; Lefeuvre, L.; Misery, L.; et al. TRPV1 and TRPA1 in cutaneous neurogenic and chronic inflammation: Pro-inflammatory response induced by their activation and their sensitization. Protein Cell 2017, 8, 644-661. [CrossRef]

26. Sadowska, A.; Hitzl, W.; Jaszczuk, P.; Cherif, H.; Haglund, L.; Hausmann, O.; Wuertz-Kozak, K. Differential regulation of TRP channel gene expression by intervertebral disc degeneration and back pain. Sci. Rep. 2018. in revision.

27. Flegel, C.; Schobel, N.; Altmuller, J.; Becker, C.; Tannapfel, A.; Hatt, H.; Gisselmann, G. RNA-Seq Analysis of Human Trigeminal and Dorsal Root Ganglia with a Focus on Chemoreceptors. PLoS ONE 2015, 10, e0128951. [CrossRef]

28. Asmar, A.; Barrett-Jolley, R.; Werner, A.; Kelly, R., Jr.; Stacey, M. Membrane channel gene expression in human costal and articular chondrocytes. Organogenesis 2016, 12, 94-107. [CrossRef]

29. Gees, M.; Alpizar, Y.A.; Boonen, B.; Sanchez, A.; Everaerts, W.; Segal, A.; Xue, F.; Janssens, A.; Owsianik, G.; Nilius, B.; et al. Mechanisms of transient receptor potential vanilloid 1 activation and sensitization by allyl isothiocyanate. Mol. Pharmacol. 2013, 84, 325-334. [CrossRef]

30. Everaerts, W.; Gees, M.; Alpizar, Y.A.; Farre, R.; Leten, C.; Apetrei, A.; Dewachter, I.; van Leuven, F.; Vennekens, R.; de Ridder, D.; et al. The Capsaicin Receptor TRPV1 Is a Crucial Mediator of the Noxious Effects of Mustard Oil. Curr. Biol. 2011, 21, 316-321. [CrossRef]

31. Guimaraes, M.Z.P.; Jordt, S.E. TRPA1: A Sensory Channel of Many Talents. In TRP Ion Channel Function in Sensory Transduction and Cellular Signaling Cascades; Liedtke, W.B., Heller, S., Eds.; CRC Press: Boca Raton, FL, USA, 2007; pp. 151-160.

32. The Electrophysiology Team at Nanion Technologies GmbH, Munich. TRPA1 Activation by Allyl Isothiocyanate Recorded on the Port-a-Patch ${ }^{\circledR}$. Available online: https:/ / www.nanion.de/en/products / port-a-patch/137-articles / 413-trpa1-trpa1-activation-by-allyl-isothiocyanate-recorded-on-the-port-apatch.html (accessed on 8 April 2019).

33. McNamara, C.R.; Mandel-Brehm, J.; Bautista, D.M.; Siemens, J.; Deranian, K.L.; Zhao, M.; Hayward, N.J.; Chong, J.A.; Julius, D.; Moran, M.M.; et al. TRPA1 mediates formalin-induced pain. Proc. Natl. Acad. Sci. USA 2007, 104, 13525-13530. [CrossRef]

34. Horvath, A.; Tekus, V.; Boros, M.; Pozsgai, G.; Botz, B.; Borbely, E.; Szolcsanyi, J.; Pinter, E.; Helyes, Z. Transient receptor potential ankyrin 1 (TRPA1) receptor is involved in chronic arthritis: In vivo study using TRPA1-deficient mice. Arthr. Res. Ther. 2016, 18, 6. [CrossRef]

35. Barton, N.J.; McQueen, D.S.; Thomson, D.; Gauldie, S.D.; Wilson, A.W.; Salter, D.M.; Chessell, I.P. Attenuation of experimental arthritis in TRPV1R knockout mice. Exp. Mol. Pathol. 2006, 81, 166-170. [CrossRef]

36. Szabo, A.; Helyes, Z.; Sandor, K.; Bite, A.; Pinter, E.; Nemeth, J.; Banvolgyi, A.; Bolcskei, K.; Elekes, K.; Szolcsanyi, J. Role of transient receptor potential vanilloid 1 receptors in adjuvant-induced chronic arthritis: In vivo study using gene-deficient mice. J. Pharmacol. Exp. Ther. 2005, 314, 111-119. [CrossRef]

37. Schumacher, M.A. Transient Receptor Potential Channels in Pain and Inflammation: Therapeutic Opportunities. Pain Pract. 2010, 10, 185-200. [CrossRef]

38. Aoki, Y.; Nakajima, A.; Ohtori, S.; Takahashi, H.; Watanabe, F.; Sonobe, M.; Terajima, F.; Saito, M.; Takahashi, K.; Toyone, T.; et al. Increase of nerve growth factor levels in the human herniated intervertebral disc: Can annular rupture trigger discogenic back pain? Arthr. Res. Ther. 2014, 16, R159. [CrossRef]

39. Chen, J.; Hackos, D.H. TRPA1 as a drug target-Promise and challenges. Naunyn Schmiedebergs Arch. Pharmacol. 2015, 388, 451-463. [CrossRef] 
40. De Petrocellis, L.; Moriello, A.S. Modulation of the TRPV1 channel: Current clinical trials and recent patents with focus on neurological conditions. Recent Pat. CNS Drug Discov. 2013, 8, 180-204. [CrossRef]

41. Botz, B.; Bolcskei, K.; Helyes, Z. Challenges to develop novel anti-inflammatory and analgesic drugs. Wiley Interdiscip. Rev. Nanomed. Nanobiotechnol. 2017, 9, e1427. [CrossRef]

42. Lehto, S.G.; Weyer, A.D.; Youngblood, B.D.; Zhang, M.; Yin, R.; Wang, W.; Teffera, Y.; Cooke, M.; Stucky, C.L.; Schenkel, L.; et al. Selective antagonism of TRPA1 produces limited efficacy in models of inflammatoryand neuropathic-induced mechanical hypersensitivity in rats. Mol. Pain 2016, 12. [CrossRef]

43. Kun, J.; Szitter, I.; Kemeny, A.; Perkecz, A.; Kereskai, L.; Pohoczky, K.; Vincze, A.; Godi, S.; Szabo, I.; Szolcsanyi, J.; et al. Upregulation of the transient receptor potential ankyrin 1 ion channel in the inflamed human and mouse colon and its protective roles. PLOS ONE 2014, 9, e108164. [CrossRef] [PubMed]

44. Kistner, K.; Siklosi, N.; Babes, A.; Khalil, M.; Selescu, T.; Zimmermann, K.; Wirtz, S.; Becker, C.; Neurath, M.F.; Reeh, P.W.; et al. Systemic desensitization through TRPA1 channels by capsazepine and mustard oil-A novel strategy against inflammation and pain. Sci. Rep. 2016, 6, 28621. [CrossRef] [PubMed]

45. Cayouette, S.; Lussier, M.P.; Mathieu, E.L.; Bousquet, S.M.; Boulay, G. Exocytotic insertion of TRPC6 channel into the plasma membrane upon G(q) protein-coupled receptor activation. J. Biol. Chem. 2004, 279, 7241-7246. [CrossRef]

46. Qu, Z.W.; Wang, Y.Q.; Li, X.; Wu, L.; Wang, Y.Z. TRPC6 expression in neurons is differentially regulated by NR2A-and NR2B-containing NMDA receptors. J. Neurochem. 2017, 143, 282-293. [CrossRef] [PubMed]

47. Xu, L.; Chen, Y.Q.; Yang, K.; Wang, Y.F.; Tian, L.C.; Zhang, J.; Wang, E.W.; Sun, D.J.; Lu, W.J.; Wang, J. Chronic Hypoxia Increases TRPC6 Expression and Basal Intracellular $\mathrm{Ca}^{2+}$ Concentration in Rat Distal Pulmonary Venous Smooth Muscle. PLoS ONE 2014, 9, e112007. [CrossRef] [PubMed]

48. Pritchard, S.; Erickson, G.R.; Guilak, F. Hyperosmotically induced volume change and calcium signaling in intervertebral disk cells: The role of the actin cytoskeleton. Biophys. J. 2002, 83, 2502-2510. [CrossRef]

49. Shimosato, G.; Amaya, F.; Ueda, M.; Tanaka, Y.; Decosterd, I.; Tanaka, M. Peripheral inflammation induces up-regulation of TRPV2 expression in rat DRG. Pain 2005, 119, 225-232. [CrossRef] [PubMed]

50. Qin, N.; Neeper, M.P.; Liu, Y.; Hutchinson, T.L.; Lubin, M.L.; Flores, C.M. TRPV2 is activated by cannabidiol and mediates CGRP release in cultured rat dorsal root ganglion neurons. J. Neurosci. 2008, 28, 6231-6238. [CrossRef] [PubMed]

51. Krock, E.; Rosenzweig, D.H.; Currie, J.B.; Bisson, D.G.; Ouellet, J.A.; Haglund, L. Toll-like Receptor Activation Induces Degeneration of Human Intervertebral Discs. Sci. Rep. 2017, 7, 17184. [CrossRef]

52. Krupkova, O.; Sekiguchi, M.; Klasen, J.; Hausmann, O.; Konno, S.; Ferguson, S.J.; Wuertz-Kozak, K. Epigallocatechin 3-gallate suppresses interleukin-1beta-induced inflammatory responses in intervertebral disc cells in vitro and reduces radiculopathic pain in rats. Eur. Cell. Mater. 2014, 28, 372-386. [CrossRef] [PubMed]

53. Leung, V.Y.; Chan, W.C.; Hung, S.C.; Cheung, K.M.; Chan, D. Matrix remodeling during intervertebral disc growth and degeneration detected by multichromatic FAST staining. J. Histochem. Cytochem. 2009, 57, 249-256. [CrossRef]

54. Boudes, M.; Uvin, P.; Pinto, S.; Freichel, M.; Birnbaumer, L.; Voets, T.; de Ridder, D.; Vennekens, R. Crucial role of TRPC1 and TRPC4 in cystitis-induced neuronal sprouting and bladder overactivity. PLoS ONE 2013, 8, e69550. [CrossRef]

55. Alkhani, H.; Ase, A.R.; Grant, R.; O’Donnell, D.; Groschner, K.; Seguela, P. Contribution of TRPC3 to store-operated calcium entry and inflammatory transductions in primary nociceptors. Mol. Pain 2014, 10, 43. [CrossRef]

56. Pairet, N.; Mang, S.; Fois, G.; Keck, M.; Kuhnbach, M.; Gindele, J.; Frick, M.; Dietl, P.; Lamb, D.J. TRPV4 inhibition attenuates stretch-induced inflammatory cellular responses and lung barrier dysfunction during mechanical ventilation. PLoS ONE 2018, 13, e0196055. [CrossRef]

57. Hummel, D.M.; Fetahu, I.S.; Groschel, C.; Manhardt, T.; Kallay, E. Role of proinflammatory cytokines on expression of vitamin D metabolism and target genes in colon cancer cells. J. Steroid Biochem. Mol. Biol. 2014, 144 Pt A, 91-95. [CrossRef]

58. Haraguchi, K.; Kawamoto, A.; Isami, K.; Maeda, S.; Kusano, A.; Asakura, K.; Shirakawa, H.; Mori, Y.; Nakagawa, T.; Kaneko, S. TRPM2 Contributes to Inflammatory and Neuropathic Pain through the Aggravation of Pronociceptive Inflammatory Responses in Mice. J. Neurosci. 2012, 32, 3931-3941. [CrossRef] 
59. Ramachandran, R.; Hyun, E.; Zhao, L.N.; Lapointe, T.K.; Chapman, K.; Hirota, C.L.; Ghosh, S.; McKemy, D.D.; Vergnolle, N.; Beck, P.L.; et al. TRPM8 activation attenuates inflammatory responses in mouse models of colitis. Proc. Natl. Acad. Sci. USA 2013, 110, 7476-7481. [CrossRef]

60. Wuertz, K.; Haglund, L. Inflammatory Mediators in Intervertebral Disk Degeneration and Discogenic Pain. Glob. Spine J. 2013, 3, 175-184. [CrossRef]

61. Brew, K.; Nagase, H. The tissue inhibitors of metalloproteinases (TIMPs): An ancient family with structural and functional diversity. Biochim. Biophys. Acta Mol. Cell Res. 2010, 1803, 55-71. [CrossRef]

62. Hilario, M.O.; Terreri, M.T.; Len, C.A. Nonsteroidal anti-inflammatory drugs: Cyclooxygenase 2 inhibitors. J. Pediatr. 2006, 82 (Suppl. 5), S206-S212. [CrossRef]

(C) 2019 by the authors. Licensee MDPI, Basel, Switzerland. This article is an open access article distributed under the terms and conditions of the Creative Commons Attribution (CC BY) license (http://creativecommons.org/licenses/by/4.0/). 